\title{
Role of KIR Receptor in NK Regulation during Viral Infections
}

\author{
Sabrina Rizzo ${ }^{+}$, Giovanna Schiuma ${ }^{+}$(D), Silvia Beltrami $(\mathbb{D}$, Valentina Gentili $\mathbb{D}$, Roberta Rizzo *(D) \\ and Daria Bortolotti * (D)
}

Citation: Rizzo, S.; Schiuma, G.; Beltrami, S.; Gentili, V.; Rizzo, R.; Bortolotti, D. Role of KIR Receptor in NK Regulation during Viral Infections. Immuno 2021, 1, 305-331. https://doi.org/10.3390/immuno 1030021

Academic Editor:

Alessandra Fierabracci

Received: 30 July 2021

Accepted: 2 September 2021

Published: 6 September 2021

Publisher's Note: MDPI stays neutral with regard to jurisdictional claims in published maps and institutional affiliations.

Copyright: (C) 2021 by the authors. Licensee MDPI, Basel, Switzerland. This article is an open access article distributed under the terms and conditions of the Creative Commons Attribution (CC BY) license (https:// creativecommons.org/licenses/by/ $4.0 /)$.
Department of Chemical, Pharmaceutical and Agricultural Sciences, University of Ferrara, 44121 Ferrara, Italy; sabrina.rizzo@unife.it (S.R.); giovanna.schiuma@unife.it (G.S.); silvia.beltrami@unife.it (S.B.); valentina.gentili@unife.it (V.G.)

* Correspondence: rbr@unife.it (R.R.); brtdra@unife.it (D.B.)

+ These authors contributed equally to this work.

\begin{abstract}
Natural Killer (NK) cells are key effectors of the innate immune system which represent the first line of defense against viral infections. NK cell activation depends on the engagement of a complex receptor repertoire expressed on their surface, consisting of both activating and inhibitory receptors. Among the known NK cell receptors, the family of killer Ig-like receptors (KIRs) consists in activating/inhibitory receptors that interact with specific human leukocyte antigen (HLA) molecules expressed on target cells. In particular, the expression of peculiar KIRs have been reported to be associated to viral infection susceptibility. Interestingly, a significant association between the development and onset of different human pathologies, such as tumors, neurodegeneration and infertility, and a clonal KIRs expression on NK cells has been described in presence of viral infections, supporting the crucial role of KIRs in defining the effect of viral infections in different tissues and organs. This review aims to report the state of art about the role of KIRs receptors in NK cell activation and viral infection control.
\end{abstract}

Keywords: NK cells; KIR receptors; viral infections

\section{Introduction}

Natural Killer (NK) cells are large granular lymphocytes belonging to the innate immune system present at both systemic level, where they constitute nearly $10-15 \%$ of the circulating lymphocytes [1], and in association to tissues [2,3]. Peripheral or tissueassociated NK cells display different behaviors: circulating NK cells are characterized by a cytotoxic profile, while tissue NK cells are typically secretory cells [4]. In particular, this latter type of NK cells has been reported in secondary lymphoid organs [5], inflammatory sites [6], and also in endometrium [7], where they are the predominant lymphocyte population playing important roles in reproduction $[8,9]$, particularly during implantation and decidualization.

In general, NK cells are described as large lymphocytes that lack the expression of canonical $\mathrm{T}$ cell receptors (i.e., CD3 negative), thus human NK cells have been classically defined as $\mathrm{CD}^{-}{ }^{-} \mathrm{CD} 56^{+}$. Besides these classical NK cells, later evidence has identified another set of NK cells, called NKT cells, that have been found within T cell populations and express both TCR molecules and NK cell markers [10]. Nevertheless, NKT cells show a restricted TCR repertoire and constitute a small percentage of cells found in thymus and spleen, but they are significantly present in the liver [10]. An additional NK cell population, showing both $\mathrm{T}$ cell and NK cell phenotypes, has been identified as Cytokine-induced killer (CIK) cells. These cells express either the T cell marker CD3 or NK-cell marker CD56 and exert a peculiar strong cytotoxic activity [11]. CIK cells are expandable from peripheral blood mononuclear cells and differentiate in presence of specific cytokines, like IL-15 and IL-2 [11,12].

However, classical NK cells are generally further subdivided into CD56 ${ }^{\text {bright }}$ and CD56 ${ }^{\text {dim }}$ NK cells. The substantial difference between the two groups is that CD56 ${ }^{\text {bright }} \mathrm{NK}$ 
cells are much more abundant in tissues and lack the expression of CD16 (Fc $\gamma$-receptor) and typically exert a secretory function, while CD 56 dim NK cells are predominant in peripheral blood, express CD16, and are characterized by a peculiar cytotoxic activity [13]. The presence of CD16 allows circulating NK cells to recognize the constant fraction (Fc) of antibodies and to engage cell lysis [14].

In addition to CD56 $6^{\text {bright }}$ and CD56 ${ }^{\text {dim }}$ classification, a subset of $\mathrm{CD} 56^{-} \mathrm{CD} 16^{+} \mathrm{NK}$ cells appear to be expanded in the presence of chronic viral infections, for example, HIV-1 (human immunodeficiency virus-1), and they seem to represent an exhausted/anergic subset of NK cells $[15,16]$.

NK cells have also been classified into NK1 and NK2 subsets, based on their cytokine release [17] and on their chemokine receptors expression [18]. NK1 and NK2 produce both T helper type 1 (Th1) and Th2 cytokines, through which they can exert beneficial, as well as deleterious, effects in a variety of inflammatory diseases, playing an immunomodulatory role in cellular response [19]. Later studies have further investigated another NK1 subset, that secretes Th17-related cytokines, such as IL-17, called NKTh17 [19]. This novel subset of human NK cells is phenotypically characterized by the presence of CD56, CCR4, and IL-23 receptors and by the ability to produce IL-17 [20]. In particular, Rizzo et al. have observed that, during Herpes simplex virus (HSV)-1 infection, NKTh17 KIR2DL2+ cells produced high levels of Th17 cytokines, mainly IL-17A [21]. The production of IL-17 by NKTh17 might induce the upregulation of anti-apoptotic molecules, consequently increasing persistent infection by blocking cytotoxic T cells action [22].

NK cells represent the first line of defense against viral infections and their relevance is confirmed by the several mechanisms used by viruses to evade NK cell-mediated immune responses [23], that is characterized also by a memory-like status [14]. Even if immunological memory is a characteristic hallmark of the adaptive immune system, NK cells have been shown to mediate Ag-specific recall responses too. NK cell memory is the consequence of a clonal-like expansion during viral infection that generates a long-lived progeny (i.e., memory cells) that triggers a more efficacious secondary response against previously encountered pathogens [24].

The contribution of NK cells to the antiviral immune response has been extensively studied in mouse models of viral infections, demonstrating that these types of cells not only control viral replication by killing infected cells during the earliest stages of infection, prior to the development of adaptive immunity, but play a crucial immunoregulatory role during the development of adaptive immune response as well $[25,26]$. The ability of NK cells to modulate adaptive immunity is mediated by the secretion of cytokines, such as interferons and interleukins, able to stimulate adaptive immunity cells, as T- and B-cells, triggering their activation.

Several works found that an impairment in NK cell activity, for example due to NK cell deficiencies in humans $[27,28]$, could enhance viral infections, including multiple infections by herpesviruses. The authors first reported a case of a young girl who lacked functional NK cells and experienced a series of viral infections during childhood and adolescence, including infections by multiple herpesviruses, highlighting the importance of NK cells contribution to the antiviral immune response [27].

In particular, during viral infections, both cytotoxic and secretory NK cells activation can be stimulated by specific cytokines upregulated during viral replication (Figure 1). For example, type-I interferons (IFN- $\alpha / \beta$ ), secreted by infected cells, induce NK cells cytotoxicity [10]; the expression of IL-12 (interleukin-12) stimulates NK cells IFN- $\gamma$ (interferon- $\gamma$ ) secretion [29]. This latter can activate multiple important pathways associated with direct antiviral functions and/or immunoregulatory effects on downstream immune response. Meanwhile, NK cells can also produce TNF- $\alpha$ (tumor necrosis factor- $\alpha$ ) that mediates antiviral and immunoregulatory effects $[10,30]$. 


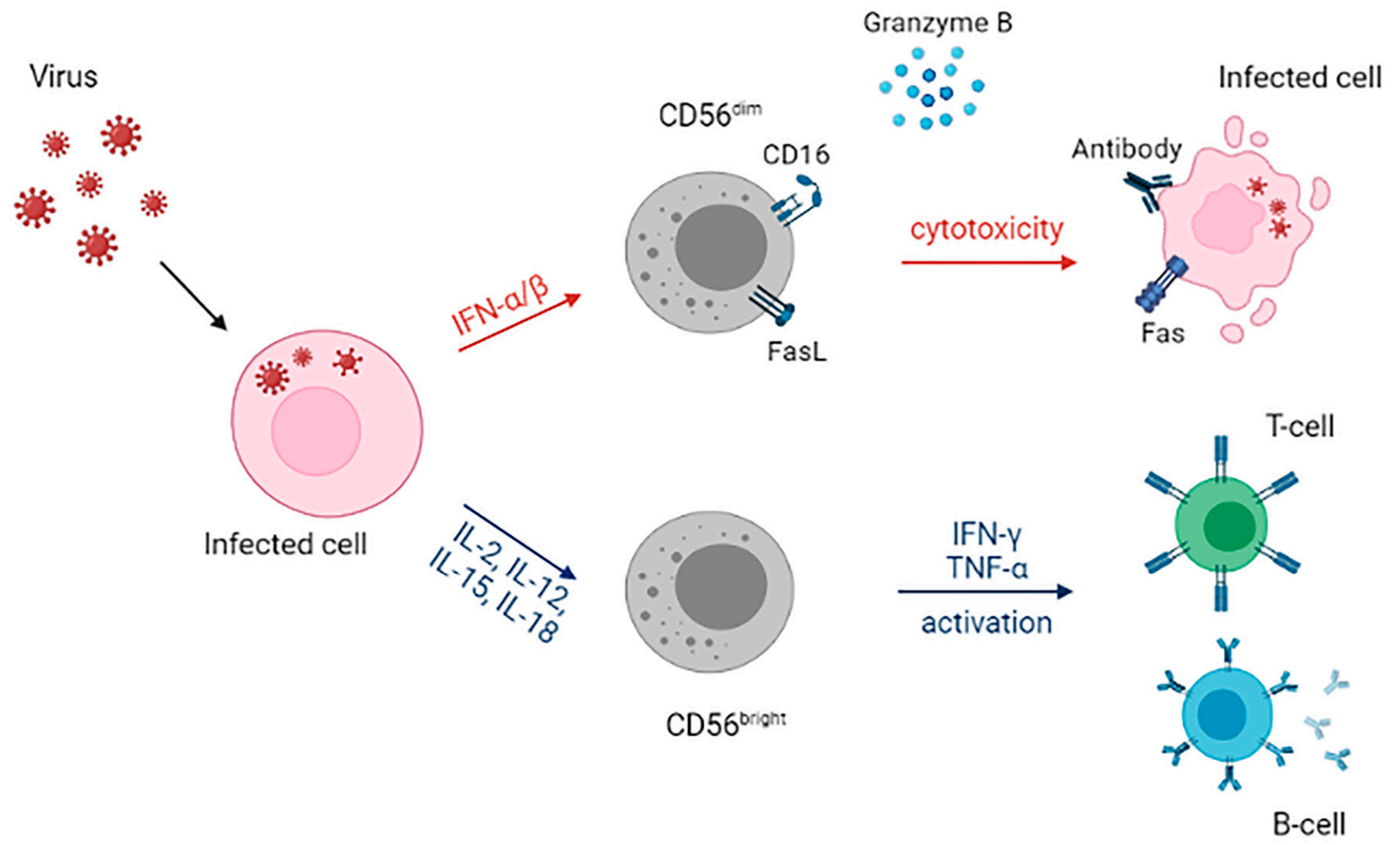

Figure 1. NK cell activation during infection. Virus can induce the production of IFN- $\alpha /-\beta$ (interferon- $\alpha /-\beta)$ and IL (interleukin)-2, IL-12, IL-15, and IL-18 by infected cells, which respectively stimulate NK cells cytotoxicity and adaptive immunity activation. CD56 ${ }^{\text {dim }}$ NK cells have a cytotoxic function that can be mediated by Granzyme-B production, Fas/FasL (Fas ligand) interaction and CD16 binding with the Fc (constant fraction) of antibodies. Adaptive immunity modulation is mediated by CD56 $6^{\text {bright }}$ NK cells through the secretion of IFN- $\gamma$ (interferon- $\gamma$ )/TNF- $\alpha$ (tumor necrosis factor- $\alpha$ ), that affect T- and B-cells.

Besides the aforementioned IFNs and IL-12, also IL-2, IL-15, and IL-18 participate in NK cells early activation. During inflammation or viral infection, secreted IL-2, IL-12, and IL-18 drive NK cell activation inducing target cell killing and the release of cytotoxic cytokines [31-33]. IL-2 and IL-15 are mainly involved in NK cell "priming". Both IL-2 and the "IL-2-like" IL-15 achieve their functions by binding the heterotrimeric receptor composed of CD132, CD122, and IL-2R $\alpha$ (CD25) for IL-2 [34] or IL-15R $\alpha$ for IL-15 binding [35]. Interestingly, IL-15 can activate NK cells with relatively lower concentrations compared to IL-2, thanks to its higher affinity for IL-15R $\alpha$ [35]. Moreover, it was found that prior exposure to IL-15 sensitizes NK cells to secondary stimuli, thereby resulting in exaggerated responses [36,37]. In fact, IL-15-primed NK cells produce elevated levels of IL-12-induced IFN- $\gamma$ [38]. Consequently, IL-15 promotes NK cells to be fully equipped to counteract viral infections through the rapid induction of granzymes and perforin [39]. IL-12 and IL-18 stimulate cytokine-induced memory-like NK cells [40], effective in response to viral infection reactivation.

After the initial activation triggered by cytokines, NK cell later activation involves specific receptors engagements and leads to their cytotoxic effect.

NK cells cytotoxicity during viral infections is mediated by different mechanisms, depending on the NK cell phenotype. Phenotypically immature $\mathrm{CD} 161^{+} / \mathrm{CD} 56^{-} \mathrm{NK}$ cells mediate TRAIL (TNF-related apoptosis-inducing ligand)-dependent but not FasL- or granule release-dependent cytotoxicity, whereas mature $\mathrm{CD} 56^{+} \mathrm{NK}$ cells mediate the latter two [41], as exocytosis of cytoplasmatic granules containing perforin and Granzyme-B, Fas ligand-mediated induction of apoptosis and antibody-dependent cellular cytotoxicity (ADCC) through CD16 binding with the Fc of antibodies (Figure 1) [23]. 
NK cells effector functions are regulated by the combination of activating and inhibitory signals triggered by specific receptor/ligand interactions [14] that determine infected cells killing and regulation of antigen presenting cells (APC) and T cells responses through soluble factors secretion (such as IFN- $\gamma$ and TNF- $\alpha$ ), as represented in Figure 2 [14].
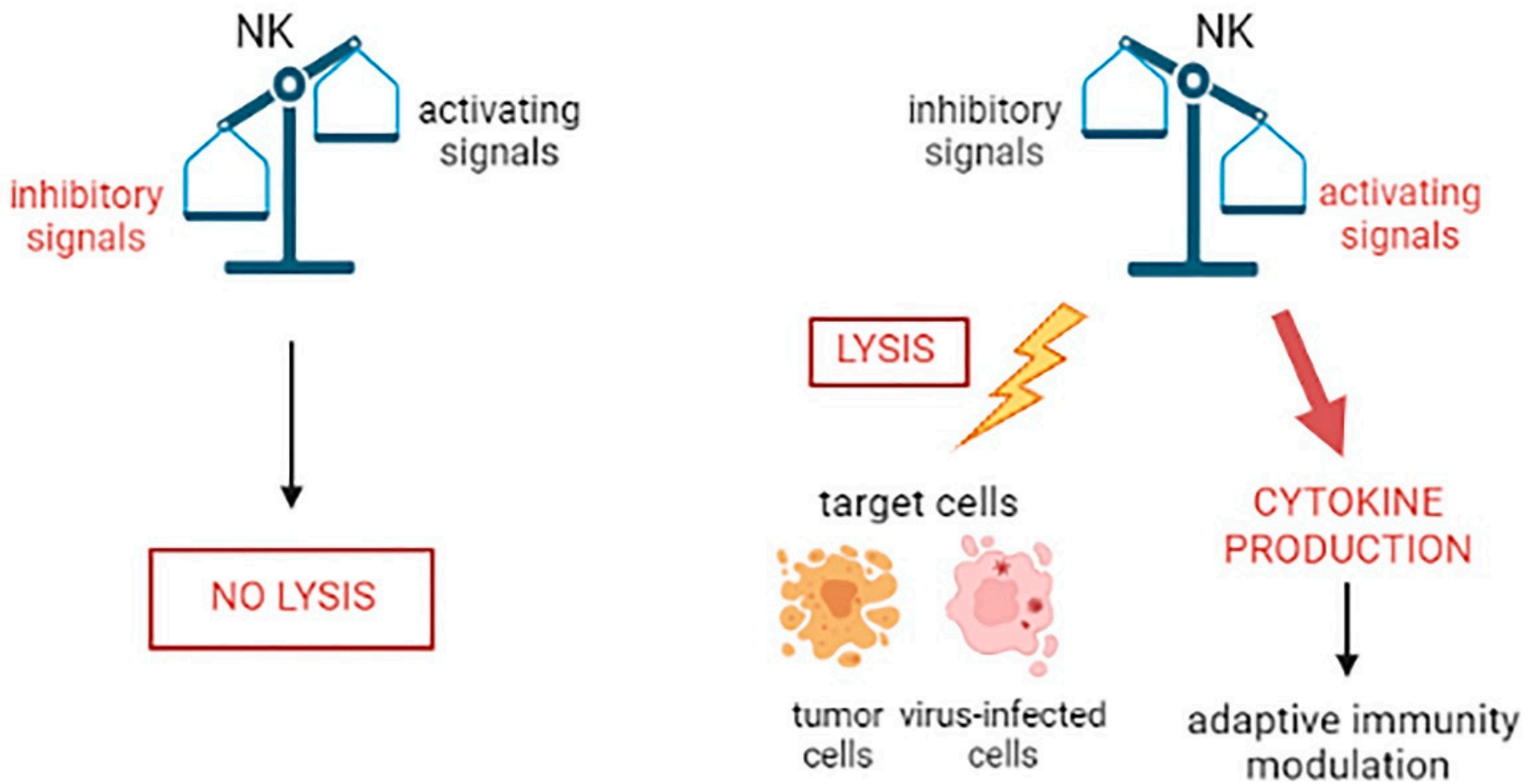

Figure 2. NK cells effector functions regulation by activating and inhibitory signals combination. Depending on the prevalence of inhibitory or activating environmental signals, NK cells can be respectively inhibited or stimulated to lyse target cells (tumor or infected) or to produce cytokine.

Both innate and adaptive immune system exert their function engaging specific receptors which are genetically determined. Unlike adaptive lymphocytes, wherein receptor diversity is generated by DNA rearrangements, NK cells express an array of germ-line encoded receptors capable of triggering their activation [42-45]. Despite this difference, NK cells display some features of adaptive immunity, placing these cells in the middle of the two types of immune system [46]. This peculiarity is due to NK cell cytotoxic/cytolytic activity towards tumor or infected cells typically via perforin or Granzyme-B secretion [23,47], that resembles CD8+ T lymphocytes killing, regulated by specific receptor engagement [11].

In this review we are going to analyze the important role of these receptors in NK cells regulation during viral infections, with particular attention to Killer immunoglobulin-like receptors (KIRs).

\section{NK Receptors}

The mechanisms by which NK cells recognize virally infected target cells are complex and still not entirely understood. Unlike B and T cells, NK cells do not express unique clonally distributed receptors for specific antigens, but they express on their surface an arsenal of different stimulatory and inhibitory receptors, whose engagement enables NK cells activity [43].

Membrane receptors invoked during NK cells regulation can be classified into five major families of molecules: natural cytotoxicity receptors (NCRs), C-type lectin, killer immunoglobulin-like receptors (KIR), leukocyte immunoglobulin-like receptors (LILR), and CD2. 
The main molecular families, ligands, and regulatory functions of NK cell activating/inhibitory receptors are described below in Table 1.

Table 1. Principal NK cell receptors (activating and inhibitory) and ligands.

\begin{tabular}{|c|c|c|c|}
\hline Receptor Family & Receptor & Known Ligand & Function \\
\hline \multirow{3}{*}{ NCR } & NKp46 & $\begin{array}{l}\text { Viral HA, HSPG, } \\
\text { PfEMP-1 }\end{array}$ & Activating \\
\hline & NKp30 & $\begin{array}{c}\text { BAT-3, HCMV pp65, } \\
\text { B7-H6, }\end{array}$ & Activating \\
\hline & NKp44 & $\begin{array}{c}\text { HSPG, PfEMP-1, Viral } \\
\text { HA, HSPG }\end{array}$ & Activating \\
\hline \multirow{5}{*}{ C-type lectin } & CD94/NKG2A & HLA-E & Inhibitory \\
\hline & CD94/NKG2C & HLA-E & Activating \\
\hline & CD94/NKG2E & HLA-E & Activating \\
\hline & NKG2D & MICA/B, ULBPs & Activating \\
\hline & NKR-P1A & LLT1 & Inhibitory \\
\hline \multirow{12}{*}{ KIR } & KIR2DL1 & HLA-C2 (Lys 80) & Inhibitory \\
\hline & KIR2DL2/3 & HLA-C1 (Asn 80) & Inhibitory \\
\hline & KIR2DL4 & HLA-G & Activating \\
\hline & KIR2DL5 & Unknown & Inhibitory \\
\hline & KIR2DS1 & HLA-C2 (Lys 80) & Activating \\
\hline & KIR2DS2 & HLA-C1 (Asn 80) & Activating \\
\hline & KIR2DS3 & Unknown & Activating \\
\hline & KIR2DS4 & HLA-Cw4 & Activating \\
\hline & KIR2DS5 & Unknown & Activating \\
\hline & KIR3DL1 & HLA-Bw4 & Inhibitory \\
\hline & KIR3DS1 & HLA-Bw4 (possible) & Activating \\
\hline & KIR3DL2 & HLA-A3/A11 & Inhibitory \\
\hline LILR & LILRB1/ILT2/LIR-1 & HLA class I, UL18 & Inhibitory \\
\hline \multirow{5}{*}{$\mathrm{CD} 2$} & 2B4 & CD48 & Activating/Inhibitory \\
\hline & CD2 & CD58 & Activating \\
\hline & NTB-A & NTB-A & Activating \\
\hline & CRACC & CRACC & Activating \\
\hline & DNAM-1 & PVR, CD122 & Activating \\
\hline CEACAM & CEACAM1 & $\begin{array}{l}\text { NKG2D } \\
\text { receptor-ligand } \\
\text { system }\end{array}$ & Inhibitory \\
\hline \multirow{2}{*}{ TIGIT } & CD96 & CD155 & Inhibitory \\
\hline & TIGIT & $\begin{array}{l}\text { CD112, CD113, } \\
\text { CD155 }\end{array}$ & Inhibitory \\
\hline TIM & Tim-3 & $\begin{array}{l}\text { Ceacam-1, PtdSer, } \\
\text { Galectin-9 }\end{array}$ & Inhibitory \\
\hline DC-SIGN & Lag-3 & $\begin{array}{l}\text { HLA class II, IL-2R, } \\
\text { IL-15R }\end{array}$ & Inhibitory \\
\hline $\begin{array}{l}\text { Type I cytokine } \\
\text { receptor }\end{array}$ & $\begin{array}{l}\text { IL-2R } \alpha \\
\text { IL-15R } \alpha\end{array}$ & $\begin{array}{c}\text { IL-2 } \\
\text { IL-15 }\end{array}$ & $\begin{array}{l}\text { Activating } \\
\text { Activating }\end{array}$ \\
\hline
\end{tabular}

Abbreviations: NCR (natural cytotoxicity receptors); KIR (killer immunoglobulin-like receptors); LILR (leukocyte immunoglobulin-like receptors); CEACAM (carcinoembryonic antigen-related cell adhesion molecules); TIGIT (T cell immunoreceptor with Ig and ITIM domains); TIM (T cell/transmembrane, immunoglobulin, and mucin); DC-SIGN (dendritic cell-specific ICAM-3-grabbing non-integrin); HLA (human leukocyte antigen); BAT-3 (HLAB-associated transcript 3); HA for hemagglutinin; HSPG for heparan sulfate proteoglycan; PfEMP-1 for Duffybinding-like (DBL)-1 $\alpha$ of Plasmodium falciparum erythrocyte membrane protein-1; ULBP for UL16-binding protein; PtdSer for phosphatidyl serine. 
Most human NK cells constitutively express the activating receptors NKp46 and NKp30, which belong to NCRs family. NCRs include NKp44 receptor as well, which is only detected on cell surface upon IL-2 mediated NK cell activation [48]. The precise ligands for these receptors remain largely undefined, even if several viral- or tumor-associated molecules that can interact with NCRs have been identified [49]. Interestingly, NKp46 and NKp44 can interact with influenza hemagglutinin (HA) and mediate NK cytolysis of infected cells expressing viral glycoproteins [50,51].

CD94-NKG2A/C/E heterodimers are highly conserved NK receptors which belong to the family of C-type lectins, involved in both activating and inhibitory signals. Inhibitory CD94-NKG2A and activating CD94-NKG2C/E heterodimers bind the non-classical HLA (Human Leukocyte Antigen) E molecule loaded with peptides derived from other HLA class I molecules, thereby monitoring the overall expression level of HLA class I antigens. Concerning NKG2D receptor, it recognizes ligands typically expressed by stressed, malignant, or infected cells, as for example cytomegalovirus (CMV) glycoprotein UL16-binding proteins (ULBPs) and the HLA class I chain-related molecules MIC (MHC class I chainrelated protein) A and B. Nevertheless, viruses have evolved multiple mechanisms to evade recognition by NKG2D+ positive NK cells [23], including Epstein Barr virus (EBV), adenovirus, and HIV [52]. Interestingly, Carcinoembryonic antigen-related cell adhesion molecule 1 (CEACAM1) was found expressed on activated NK cells where it acts as an inhibitory receptor for NKG2D-mediated cytolysis.

NK cells are characterized by a plethora of activating/inhibitory receptors such as CD96 and TIGIT (T cell immunoreceptor with Ig and ITIM domains), that interact with CD155, CD112, and CD113; Tim-3 (T cell immunoglobulin-3), an NK cell coreceptor; Lag-3 (lymphocyte activation gene 3 protein), a negative co-inhibitory receptor that binds HLA-II molecules [53]; cytokine receptors such as IL-2R and IL-15R, as previously reported.

However, among all the reported receptors involved in NK cell regulation, the family of killer Ig-like receptors (KIRs) is one of the most studied, consisting in both activating and inhibitory receptors that bind to specific HLA-I molecules and act as key regulators of human NK cell function [54].

\section{Killer Immunoglobulin-like Receptors (KIRs)}

Killer immunoglobulin-like receptors (KIRs) are a family of transmembrane glycoproteins encoded by 15 highly polymorphic genes, whose members are characterized by distinct structural domains that determine distinct functions by providing different docking sites for ligands or signaling proteins [54]. The KIRs nomenclature was designed to reflect the structure and the function of the molecules, as well as the nucleotide sequence similarity among the different KIR family members. Thus, the first two digits following the acronym "KIR" correspond to the number of the extracellular domains (2D and 3D), while the third digit provides information on the length of the cytoplasmic tail ( $\mathrm{L}$ or S) and consequently reveals details about protein function (inhibitory or activating, respectively) [55]. The only exception to this short/long-tailed rule is KIR2DL4, which is a unique long-tailed activating KIR (Figure 3).

The two-(2D) and three-(3D) immunoglobulin domain KIR isoforms with a long cytoplasmic tail are characterized by two sequences called immunoreceptor tyrosine-based inhibitory motifs (ITIMs), separated by $26-28$ aminoacids (Figure 3) [56,57]. Molecular analysis of several membrane receptors with inhibitory function revealed the presence of a common ITIM motif (I/VxYxxL/V), which recruits the SHP-1 tyrosine phosphatase and arrests positive signals transduced via other receptors [58].

In contrast, KIRs with short cytoplasmic domains and with activating function associate with a transmembrane signalling adaptor protein which is called DAP12 (also called KARAP) [54]. DAP12-dependent activation occurs through the recruitment of Syk/ZAP-70 tyrosine kinases by immunoreceptor tyrosine-based activation motifs [ITAM; Yxx(L/I/V)x$\mathrm{Yxx}(\mathrm{L} / \mathrm{I} / \mathrm{V})$ ] (Figure 3) [54]. An exception to these two classification is represented by KIR2DL4, which compared with other long cytoplasmic tail KIR family members, behaves 
like an activating receptor, inducing cytokines production [59] due to the association with ITAM-containing FceRI- $\gamma$ adaptor instead of DAP12 (Figure 3) [60].

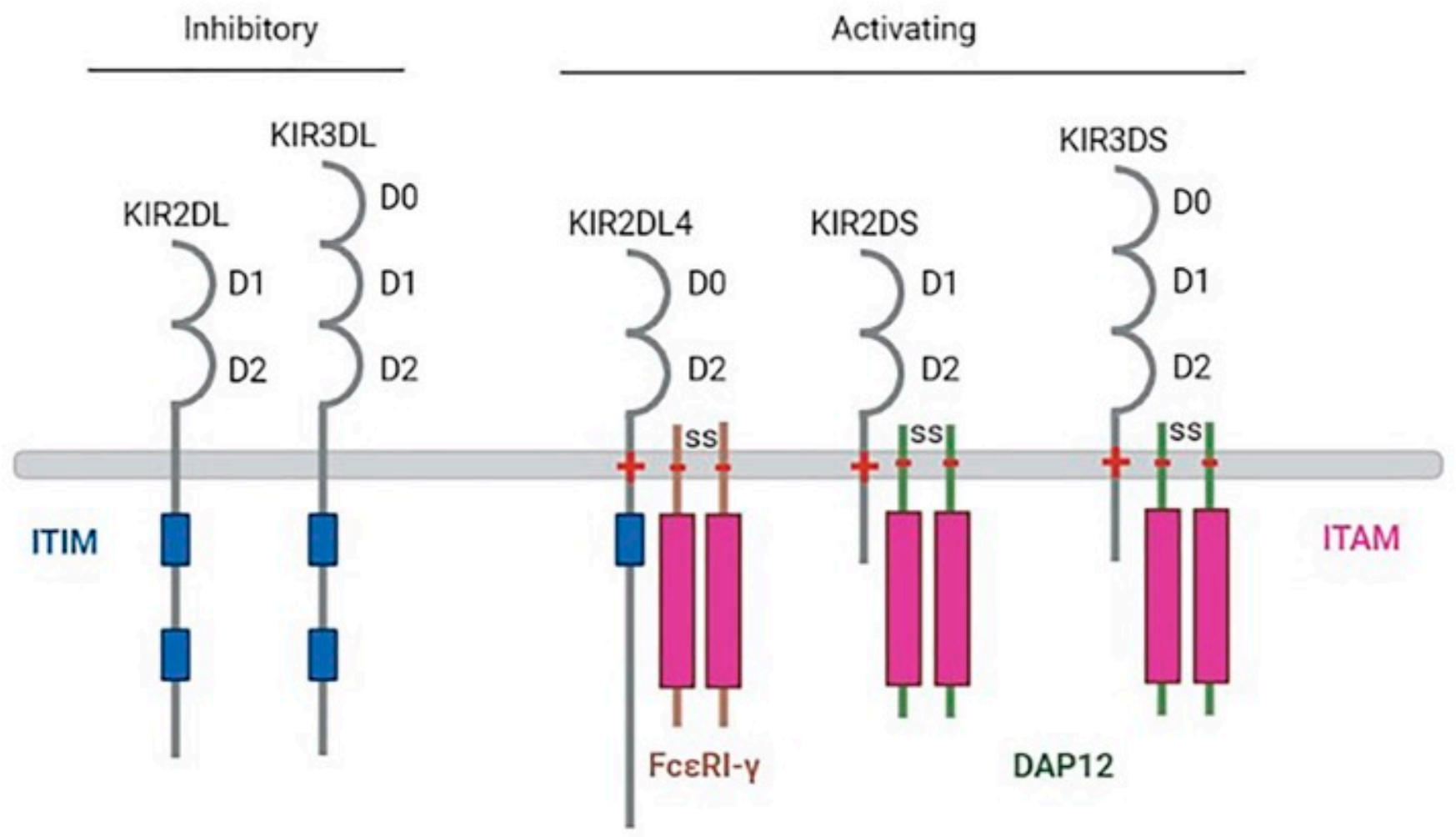

Figure 3. Representation of inhibitory and activating KIRs structure. Receptors with long cytoplasmic domains contain one or two immunoreceptor tyrosine-based inhibitory motif sequences (ITIMs), represented in blue, that provide inhibitory function. The short cytoplasmic KIR and the long-tailed KIR2DL4 are activating receptors, which contain a basic amino acid (+) within the transmembrane domain that interacts with an acidic amino acid (-) within the transmembrane domains of signaling adaptor proteins DAP12 (green) or FceRI-c (brown), respectively. These adaptors provide intracellular immunoreceptor tyrosine-based activator motif sequences (ITAMs), in purple, that allow activating function.

To date, little is known about the tyrosine kinases and phosphatases implicated in KIRs ITIM domain phosphorylation. A potential role for the $l c k$ src tyrosine kinase family in KIRs function is suggested, since lck overexpression in NK cells has been reported to enhance KIR phosphorylation [61]. Literature also indicates that a critical substrate of the SHP-1 phosphatase recruited by KIR receptors is the p36 adapter protein [62].

The engagement of activating or inhibitory KIRs depends on both their ability to recognize and their strength in binding specific ligands expressed on target cells (Table 1) [63].

Interestingly, KIRs expression on NK cell surface is not only dependent on the genetic background but also seems to be influenced by the presence of specific HLA-I ligands [64].

HLA-I genes are located on the short arm of chromosome 6 [65] and are found on the surface of all nucleated cells. HLA-I are subdivided into "classical proteins", that include HLA-A, -B and -C, and "non classical proteins", referring to HLA-E, -F, and -G molecules. The level of HLA-I expression is modified by proinflammatory cytokines $[66,67]$. Thus, during viral infection, a general upregulation of HLA-I molecules normally occurs in order to trigger immune system activation, even if viruses have developed different strategies to decrease HLA-I expression and consequently viral epitopes exposure on infected cells, avoiding CD8+ T lymphocyte killing but consequently inducing NK cell killing activation.

Once engaged by HLA-I ligands, inhibitory KIRs transduction signal is triggered by tyrosine kinases and phosphatases activation, in order to induce NK cell inhibition.

Inhibitory KIRs have been described as three distinct protein isoforms. KIRs involved in HLA-C recognition (KIR2DL1, KIR2DL2, KIR2DL3) are usually monomeric glycopro- 
teins of $\sim 58 \mathrm{kDa}$ containing two immunoglobulin-like domains (KIR-2D) in the extracellular region [56]. KIR2DL2/3 preferentially bind HLA-C1, while KIR2DL1 preferentially binds HLA-C2, showing a stronger affinity than the former. Nevertheless, HLA-C1 is also ligand for the activating KIR2DS1 receptor, while ligands for the remaining activating KIRs still remain to be identified [68]. KIRs reactive with HLA-B (KIR3DL1) are $\sim 70 \mathrm{kDa}$ monomeric glycoproteins with three immunoglobulin-like domains (KIR-3D) [56]. KIRs reactive with HLA-A ligands (KIR3DL2) possess three immunoglobulin domains in the extracellular region $[69,70]$ and are expressed on the cell surface as bisulfide-linked homodimers composed of two $\sim 70 \mathrm{kDa}$ subunits [70].

Members of the KIR gene family are tightly clustered on human chromosome 19q13.4 and consist in 15 gene loci [71], clustered in the Leukocyte Receptor Complex (LRC) region [72]. The KIR gene family also included 2 pseudogenes, KIR2DP1 and KIR3DP1, which are part of the KIR2D genes [73] and include an inactivated pseudoexon 3 sequence [74]. These two pseudogenes are not transcribed because of sequence defects [71]; therefore, they are not involved in encoding a functional KIR molecule. However, the non-functional KIR pseudogene, KIR3DP1, can be activated through non-reciprocal recombination with functional KIR genes [73,75]. About $4.5 \%$ of the individuals of a Caucasoid population own a recombinant allele of KIR3DP1, named KIR3DP1*004, that associates tightly with gene duplications of KIR3DP1, KIR2DL4, and KIR3DL1/KIR3DS1. Despite KIR3DP1 gene being normally silent, the recombinant allele KIR3DP1*004 contains a novel promoter sequence that, consequently, allows KIR3DP1 transcription [73].

KIR genes are organized into two haplotypes defined as A and B haplotypes, which differ in number and kind of KIR genes, as shown in Figure 4 [76].

Haplotype

Centromeric

Telomeric
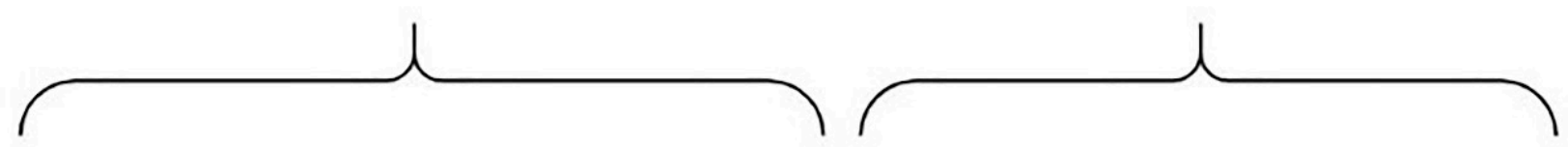

A

$3 D L 3$
$2 D P 120 L 1$

3DP1 2DL4

3DL1 $20 S 4$

\section{Framework KIR}

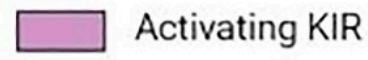

Inhibitory KIR

Figure 4. Genomic organization of KIR A haplotype and B representative haplotype. Activating KIRs are indicated in violet, inhibitory KIRs in green, framework KIRs in grey, and pseudogenes in blue.

The A haplotype is characterized by an extensive variability at allelic level [77], while B haplotype exhibits substantial variation in gene content but low allelic polymorphism [78]. $B$ haplotypes generally possess more KIR genes than group A, including mainly activating KIRs, except the haplotype B1, which is intermediate between A and B haplotypes gene content [73].

More precisely, A haplotypes are devoid of activating KIR genes, except for KIR2DS4 (even if it is frequently deleted of transmembrane and cytoplasmic tail), and mainly encode inhibitory KIRs, such as KIR2DL1, KIR2DL3, KIR3DL1, KIR2DS4, and KIR2DP1 [79]. On 
the contrary, B haplotypes present a higher KIRs variability and are characterized by the presence of at least one gene among KIR2DL2, KIR2DL5A/B, KIR2DS1, KIR2DS2, KIR2DS3, KIR2DS5, and KIR3DS1. The remaining four KIR genes, termed framework genes, are shared by both haplotypes.

Interestingly, there are several pieces of evidence in literature demonstrating that there are some associations between inheritance of certain combinations of KIRs, into A or B haplotypes, and HLA genes and susceptibility to several diseases, including viral infections [54].

\section{Modulation of KIRs/Ligands during Viral Infections and Associated Diseases}

Viruses have developed several mechanisms to counteract host immune response. Several viruses (such as herpesvirus, papillomavirus, retrovirus, poxvirus, human immunodeficiency virus, and flavivirus) are able to evade NK cell effector functions [80].

In particular, since NK cell activation depends on the loss of inhibitory signals provided by HLA-I molecules and on the expression of stress or virally induced ligands of NK cell receptors [81], modulation of KIRs expression and of their HLA-I ligands represent a key mechanism exploited during viral immune escape. In particular, KIRs modulation by viruses may involve both direct and/or indirect strategies: the direct mechanisms mainly refer to epigenetic modulation of KIR receptors, while indirect KIRs modulation is essentially based on the selective expression of KIRs main ligands, that is HLA-I molecules [80,82].

It is known that the distribution pattern of KIR receptors is entirely maintained by CpG DNA methylation and consequently their expression is controlled by DNA methyltransferase enzyme [83]. In this contest, viruses, especially those which have latency characteristic as Herpesviruses and Retroviruses, could affect KIRs expression at epigenetic level as a consequence of the modifications that occur during virus life cycle and immune system activity [84]. In fact, integrated viruses with latent cycle, as Human Immunodeficiency Virus (HIV), induce a peculiar epigenetic configuration in the infected cell with the aim to maximize virus integration [85]. In this way, viruses can take advantage by epigenetic modifications to up- or downmodulate KIRs expression on NK surface [86-88].

Otherwise, indirect processes of KIRs modulation are represented by the up/ downregulation of HLA molecules as well, that are known ligands of these receptors and particularly targeted by viruses.

In fact, the selective modulation of HLA-I expression is used by several viruses to evade immune recognition and is represented in Figure 5 [89].

This mechanism enables pathogens to escape recognition by CD8+ cytotoxic T cells (CTLs) which recognizes virus-encoded peptides presented on the surface of infected cells by class I HLA molecules, such as HLA-A and HLA-B [90].

Many viruses, such as HIV [91] and herpesviruses [92], are able to interfere with HLAI presentation of viral peptides, for example downregulating HLA-I surface expression by increasing HLA-I retention in the endoplasmic reticulum [93] or the endocytosis from the cell surface, in order to block CTL killing (Figure 5) [94].

The interplay between activating and inhibitory KIRs and their corresponding HLA ligands is likely to play a role in both viral infection susceptibility and outcome [87,95], leading to chronic viremia [96] and possibly correlated pathologies [90], as summarized in Figure 6 and Table 2.

We will report the summary on the main viral infections reported to exploit KIRs/HLAI modulation and on their possible implication in human diseases. 


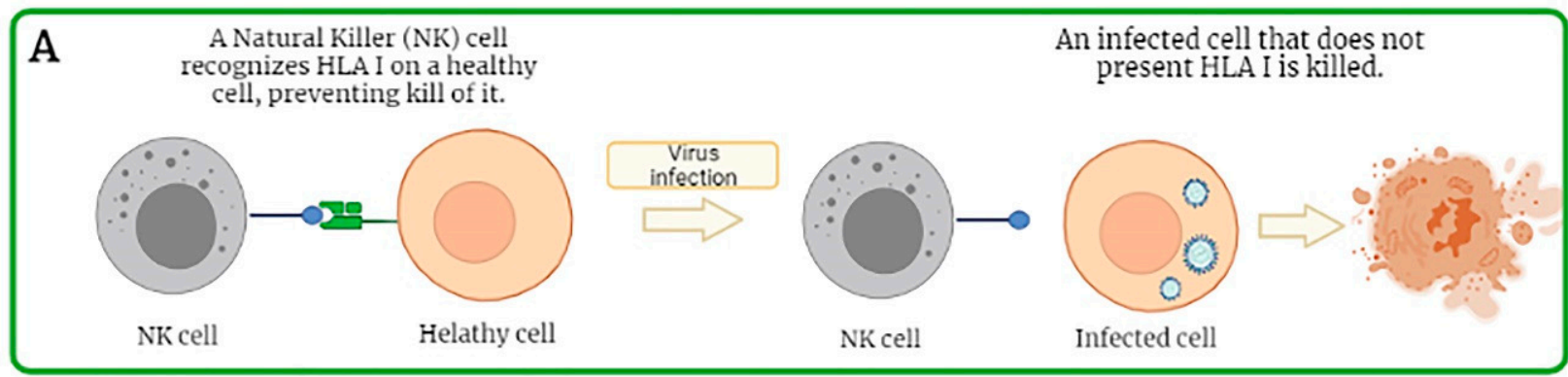

Modulation of HLA class I protein expression

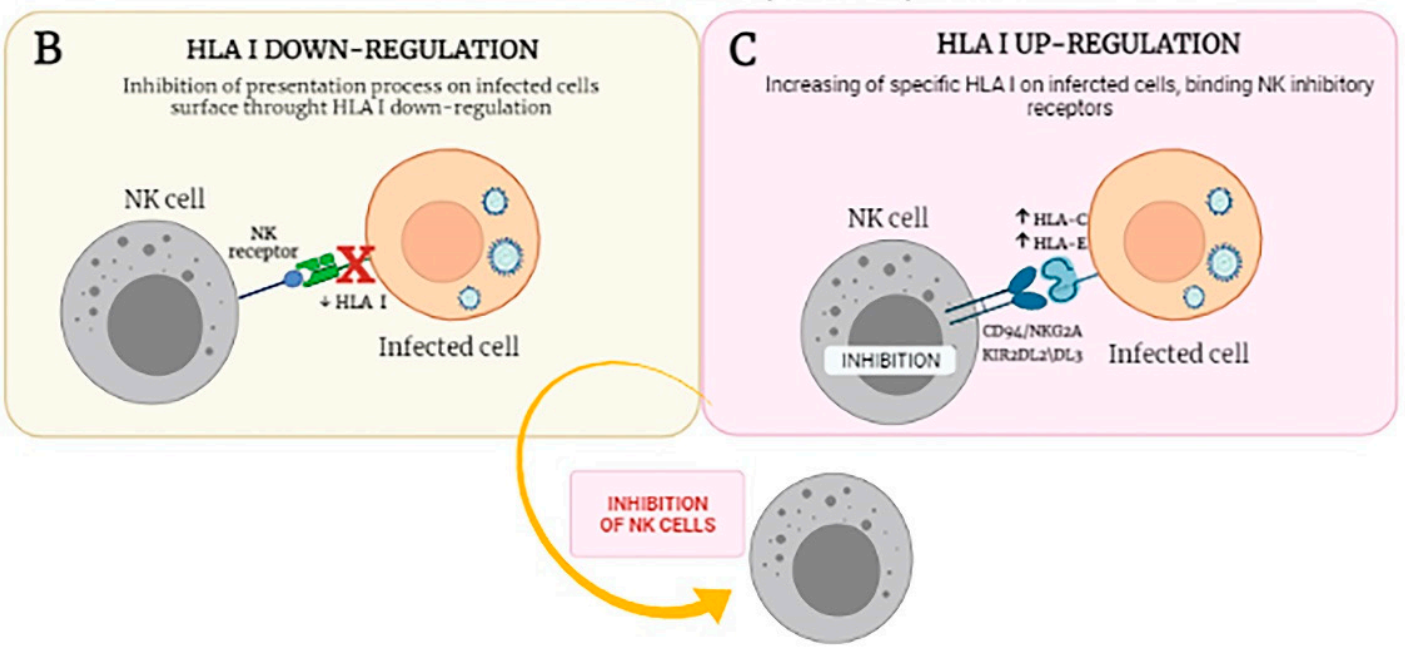

Figure 5. Representation of HLA-I dependent NK cells activation. NK cell response in presence of healthy and infected cells (A); NK cells response in presence of selective downmodulation (B) and upmodulation (C) of HLA-I protein expression by virus.
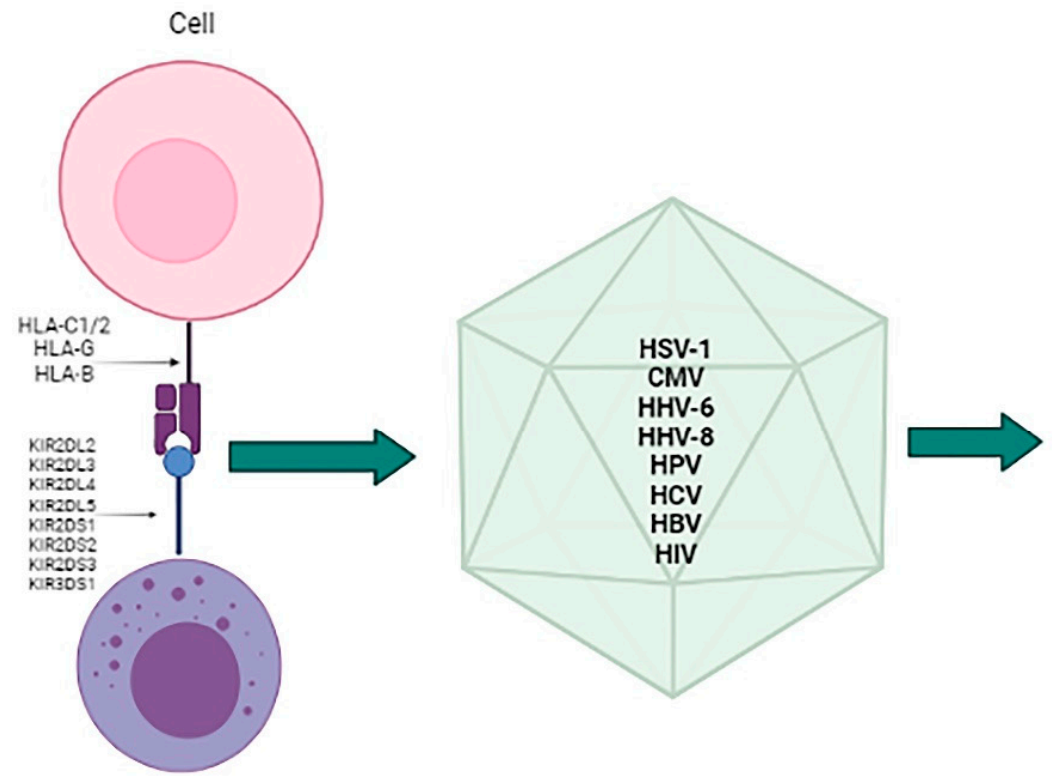

\section{Multiple Sclerosis \\ Alzheimer Disease \\ Pre-eclampsia \\ Miscarriage \\ Carcinoma}

AIDS

NK cell

Figure 6. Schematic representation of KIR/HLA class I association to viral susceptibility and diseases. The presence of particular activating (KIR2DL4, KIR2DS1, etc.) and inhibitory (KIR2DL2, KIR2DL3, etc.) KIRs, together with their specific ligands (HLA-C, HLA-G, and HLA-B), is involved in some viral infections' susceptibility and outcome (HSV-1, CMV, HIV, etc.), leading to multiple diseases like Multiple sclerosis, Alzheimer disease, Pre-eclampsia, Miscarriage, Carcinoma, and AIDS. 
Table 2. Virus and KIRs/HLA association and possibly related diseases.

\begin{tabular}{|c|c|c|c|c|}
\hline Virus & KIRs/HLA & $\begin{array}{l}\text { KIRs/HLA } \\
\text { Frequency }\end{array}$ & $\begin{array}{l}\text { System/Disease or Effect on } \\
\text { Infection Outcome }\end{array}$ & References \\
\hline \multirow{11}{*}{ CMV } & KIR2DL2 & increased & $\begin{array}{l}\text { Increased susceptibility to } \\
\text { herpetic infections }\end{array}$ & [97] \\
\hline & HLA class I & decreased & Viral immune-escape & {$[81,98]$} \\
\hline & HLA-C & Increased & Viral immune-escape & {$[89,99-101]$} \\
\hline & KIR2DS1 & increased & Control of placental CMV infection & [102] \\
\hline & KIR2DS1, KIR2DS5 & decreased & $\begin{array}{c}\text { Lower CMV infection control; abortion, } \\
\text { pre-term delivery }\end{array}$ & {$[102,103]$} \\
\hline & HLA-G/KIR2DL4 & increased & Trophoblast cells; viral immune-escape & [104] \\
\hline & KIR2DL1/HLA-C2 & increased & $\begin{array}{l}\text { immunodeficiency syndrome, recurrent } \\
\text { CMV reactivation }\end{array}$ & [105] \\
\hline & $\begin{array}{l}\text { KIR2DS2, KIR2DL3, } \\
\text { HLA-C1 }\end{array}$ & increased & $\begin{array}{c}\text { organ transplant; protection from CMV } \\
\text { reactivation }\end{array}$ & {$[106]$} \\
\hline & KIR2DL2, KIR2DS1 & increased & SLE & [107] \\
\hline & KIR2DS2 & decreased & SLE & [108] \\
\hline & KIR2DS2, KIR2DL3 & increased & Rheumatoid Arthritis; worst prognosis & [109] \\
\hline \multirow{4}{*}{ EBV } & HLA class I & decreased & \multirow{4}{*}{$\begin{array}{c}\text { Reduced NK cell killing } \\
\text { Increased risk of } \\
\text { lymphoproliferative diseases } \\
\text { Rheumatoid Arthritis; worst prognosis } \\
\text { Multiple Sclerosis, increased susceptibility } \\
\text { to herpetic infections }\end{array}$} & [93] \\
\hline & KIR2DS5, KIR2DS4 & increased & & {$[110]$} \\
\hline & KIR2DS2, KIR2DL3 & increased & & [109] \\
\hline & KIR2DL2 & increased & & [97] \\
\hline \multirow{4}{*}{ HHV-8 } & HLA class I & decreased & Viral immune-escape & [111-113] \\
\hline & KIR2DL2/HLA-C1 & increased & type- 2 diabetes & [114] \\
\hline & KIR2DL2, KIR2DS2 & increased & Cutaneous vascular lesions & [115] \\
\hline & KIR2DS1, KIR3DS1 & increased & Kaposi Sarcoma & [116] \\
\hline \multirow{6}{*}{ HHV-6 } & KIR2DL2/HLA-C1 & increased & Alzheimer's Disease, NK cell inhibition & {$[117,118]$} \\
\hline & KIR2DL2/HLA-C1 & increased & $\begin{array}{l}\text { Multiple Sclerosis, worst disease outcome, } \\
\text { NK cell inhibition, herpetic reactivation }\end{array}$ & {$[97,119,120]$} \\
\hline & HLA-G & increased & $\begin{array}{c}\text { IUGR, alterated KIR2DL4+ dNK } \\
\text { cell function }\end{array}$ & {$[121,122]$} \\
\hline & HLA-G/KIR2DL4 & decreased & Infertility; KIR2DL4+ dNK cell function & [123-127] \\
\hline & KIR2DL2 & increased & $\begin{array}{l}\text { Infertility, Multiple Sclerosis, increased } \\
\text { susceptibility to herpetic infections }\end{array}$ & {$[97,128]$} \\
\hline & KIR2DL5 & decreased & infertility & [128] \\
\hline \multirow{2}{*}{ HSV-1 } & KIR2DL2/HLA-C & increased & infertility & {$[129,130]$} \\
\hline & KIR2DL2/HLA-C & increased & Multiple Sclerosis & {$[119,120]$} \\
\hline \multirow{10}{*}{ HIV } & KIR2DL5, KIR2DS5 & increased & Protection from HIV transmission & [95] \\
\hline & HLA-C & increased & Protection from HIV transmission & [131] \\
\hline & HLA-C & increased & Viral immune-escape (via Nef protein) & {$[132]$} \\
\hline & HLA-A, HLA-B & decreased & Viral immune-escape (via Nef protein) & [133] \\
\hline & $\begin{array}{l}\text { KIR2DL2, } \\
\text { HLA-Cw*0102 }\end{array}$ & increased & Viral immune-escape (via Gag protein) & [134] \\
\hline & HLA-C & increased & Viral immune-escape (via Env protein) & {$[135,136]$} \\
\hline & KIR3DS1 & decreased & $\begin{array}{c}\text { Higher NK cell function, reduced } \\
\text { perinatal transmission }\end{array}$ & {$[137,138]$} \\
\hline & $\begin{array}{l}\text { KIR3DL1, KIR2DL2, } \\
\text { KIR2DL3, KIR2DL5, } \\
\text { KIR2DS5, HLA-C }\end{array}$ & increased & Reduced perinatal transmission & {$[139,140]$} \\
\hline & $\begin{array}{l}\text { KIR2DL2, KIR2DS2, } \\
\text { KIR2DS3, KIR2DS4, } \\
\text { KIR3DS1 }\end{array}$ & increased & Higher susceptibility in the newborn & [138] \\
\hline & KIR3DS1/HLA-Bw4-80I & increased & $\begin{array}{c}\text { Decreased AIDS progression; } \\
\text { protective effect }\end{array}$ & [141-144] \\
\hline
\end{tabular}


Table 2. Cont.

\begin{tabular}{|c|c|c|c|c|}
\hline Virus & KIRs/HLA & $\begin{array}{l}\text { KIRs/HLA } \\
\text { Frequency }\end{array}$ & $\begin{array}{l}\text { System/Disease or Effect on } \\
\text { Infection Outcome }\end{array}$ & References \\
\hline \multirow{8}{*}{$\mathrm{HBV}$} & KIR2DS1, KIR2DS2 & increased & $\begin{array}{c}\text { HBV recovered subjects, lower NK } \\
\text { cell activation }\end{array}$ & [145] \\
\hline & KIR2DL3/HLA-C1 & increased & Protective toward HBV susceptibility & [146] \\
\hline & KIR2DL3 & decreased & $\mathrm{CHB}$ & [147] \\
\hline & KIR2DL1/HLA-C2 & increased & Higher HBV infection rate & [146] \\
\hline & KIR2DS2, KIR2DS3 & increased & $\mathrm{CHB}$, increased HBV susceptibility & [148] \\
\hline & $\begin{array}{l}\text { KIR2DS1, KIR3DS1, } \\
\text { KIR2DL5, KIR2DL3 }\end{array}$ & increased & $\mathrm{CHB}$, protective effect, $\mathrm{HBV}$ clearance & [147-149] \\
\hline & HLA-C1 & increased & $\begin{array}{c}\text { Increased risk of HCC progression in } \\
\text { HBV-infected patients }\end{array}$ & [150] \\
\hline & HLA-C2, HLA-A-Bw4 & increased & Increased risk for $\mathrm{CHB}$ development & [147] \\
\hline \multirow{6}{*}{$\mathrm{HCV}$} & $\begin{array}{l}\text { KIR3DL2, KIR2DL1, } \\
\text { KIR2DL2, KIR2DL3, } \\
\text { HLA-C2 }\end{array}$ & increased & Poor HCV clearance after treatment & {$[151,152]$} \\
\hline & HLA-C $* 03: 04$, KIR2DL3 & increased & Viral immune-escape & [153] \\
\hline & HLA-B*27 /KIR3DL1 & decreased & Viral immune-escape & [154-156] \\
\hline & $\begin{array}{l}\text { KIR3DL1 } \\
\text { KIR2DS3 }\end{array}$ & $\begin{array}{l}\text { decreased } \\
\text { increased }\end{array}$ & Increased risk for chronic $\mathrm{HCV}$ infection & $\begin{array}{l}{[157]} \\
{[158]}\end{array}$ \\
\hline & HLA-Bw4/KIR3DS1 & increased & $\begin{array}{c}\text { Protective against liver disease in } \\
\text { HCV patients }\end{array}$ & [159] \\
\hline & HLA-C1/KIR2DL3 & increased & $\begin{array}{c}\text { Spontaneous infection resolution and } \\
\text { sustained response to } \mathrm{HCV} \\
\text { antiviral therapy }\end{array}$ & {$[160,161]$} \\
\hline \multirow[b]{2}{*}{ Enterovirus } & KIR3DL1 & decreased & Type- 1 diabetes & [162] \\
\hline & HLA class I & increased & $\begin{array}{l}\text { Induction of antiviral response that } \\
\text { triggers Hashimoto's } \\
\text { Thyroiditis condition }\end{array}$ & [163] \\
\hline Parvovirus & HLA-I & increased & SLE, persistent viral infection & {$[164,165]$} \\
\hline \multirow{4}{*}{ HPV } & $\begin{array}{l}\text { KIR2DL2/HLA-C1, } \\
\text { KIR2DL3/HLA-C1 }\end{array}$ & increased & $\begin{array}{c}\text { Cervix cancer, risk factor for HPV } \\
\text { high-risk infection and } \\
\text { neoplastic transformation }\end{array}$ & [166] \\
\hline & HLA-C2 & increased & $\begin{array}{c}\text { Cervix cancer, no increased risk for HPV } \\
\text { high-risk infection and } \\
\text { neoplastic transformation }\end{array}$ & [166] \\
\hline & KIR2DL1 & increased & Cervix cancer & [166] \\
\hline & KIR2DL2/HLA-C2 & decreased & Cervix cancer & [166] \\
\hline
\end{tabular}

Abbreviations: SLE (Systemic Lupus Erythematosus), HHV-8 (Human Herpesvirus 8), HHV-6 (Human Herpesvirus 6), IUGR (intrauterine growth restriction), AIDS (Acquired Immune Deficiency Syndrome), HBV (Hepatitis B virus), HCC (hepatocellular carcinoma), CHB (chronic hepatitis B), HCV (Hepatitis C virus), HPV (Human Papillomavirus).

\subsection{Herpesviruses}

Herpesviruses have developed several strategies that inhibit NK cell activation by blocking the expression of ligands of activating receptors or preserving the expression of ligands of inhibitory receptors, including HLA-I.

Human Cytomegalovirus (HCMV) viral proteins US2 and US11 have been reported to shuttle HLA-I from the endoplasmic reticulum to the cytoplasm, resulting in HLAI degradation [81,98], while UL16, UL18, and UL40 maintain a locus-restricted surface expression of HLA molecules, including HLA-C, that act as ligands for NK cells inhibitory receptors [89,99] (Table 2; Figure 7). Interestingly, HCMV-induced HLA-C expression includes specific HLA-C modification, as glycosylation [100] and formation of heterodimers with other HLA-I molecules [167-169] or with viral protein [101], that sustain a differential KIRs recruitment. 


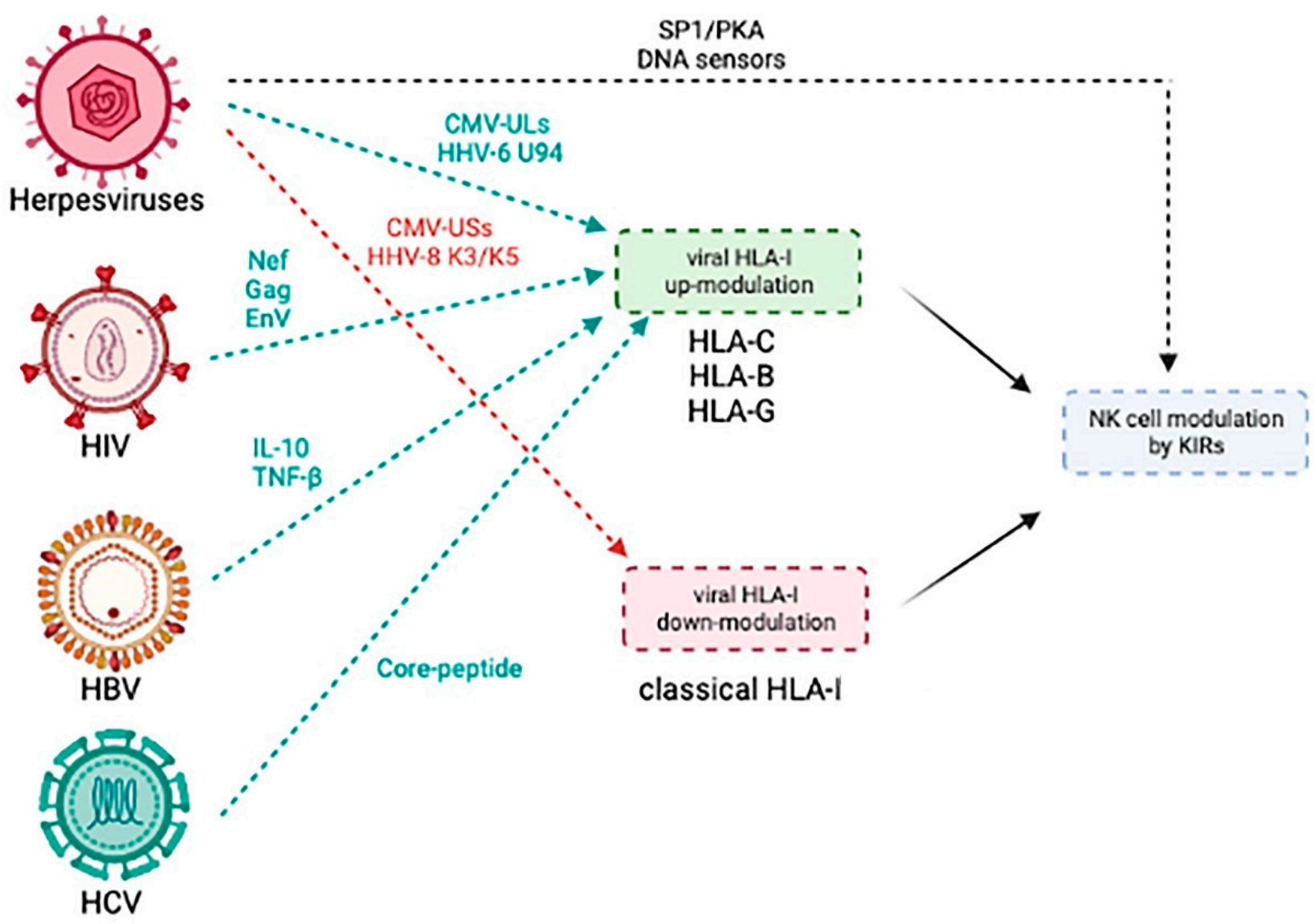

Figure 7. Schematic representation of the main viral strategy to modulate KIRs/HLA-I ligands described in the text. Viruses (e.g., Herpesviruses, HIV, HBV, and HCV) have evolved different mechanisms to modulate HLA-I molecules or induce/exploit specific KIRs expression, for example, by production of specific viral proteins to modify NK cell activation and evade host immune response.

KIRs also play a role in NK cells-mediated clearance of HCMV infection associated to congenital disorders such as spontaneous abortion or pre-term delivery (Table 2) [103]. The expression of KIR2DS1 by decidual NK (dNK) cells increases their ability to control placental HCMV infection, reducing or preventing virus-induced pathology of the placenta and improving its function. In contrast, pregnant women who lack KIR2DS1, or similarly KIR2DS5, showed a lower ability to control placental HCMV infection and developed complications (Table 2) [102].

Again, HCMV infection modifies the expression of HLA class I molecules at the surface of placental extravillous trophoblast (EVT) cells, which typically do not express HLA-A and HLA-B molecules but do express an unusual combination of HLA-E, HLA-F, and HLA-G, in addition to low levels of HLA-C. Schust et al. addressed that unlike HLA-A and $-\mathrm{B}$, both HLA-C and HLA-G expressed in a human trophoblast cell line were fully resistant to the rapid degradation associated with HCMV proteins US2 and US11 [104], mounting evidence that HLA-G could interact with KIR2DL4 expressed by decidual NK cells inducing IFN- $\gamma$ and TNF- $\alpha$ secretion and promoting viral immune escape (Table 2).

In a case study of a child with a novel immunodeficiency syndrome and recurrent HCMV infection [105], the entire population of NK cells from this patient expressed KIR2DL1 in the presence of KIR2DL1 ligand, HLA-C2, raising the possibility that the strongly inhibitory KIR2DL1/HLA-C2 combination crippled NK cell activity and prevented a protective NK cell response against HCMV (Table 2). Activating KIR expression improves the protection during HCMV reactivation in stem cell transplantation [170] and solid organ transplant, where a combination of the activating KIR2DS2 and weak inhibitory KIR2DL3, 
which share the ligand HLA-C1, in the recipient was associated with a decreased risk of CMV viremia when both donor and recipient were homozygous for HLA-C1 (Table 2) [106].

CMV has also been described associated to Systemic Lupus Erythematosus (SLE) susceptibility [171], possibly involving specific KIRs/HLA-I combinations. Hou et al. have suggested that KIR genotype and HLA ligand interaction may potentially influence the threshold for NK cells activation mediated by activating receptors, thereby contributing to the pathogenesis of SLE [172] and also to viral susceptibility. In this study an increased frequency of KIR2DL2 and KIR2DS1 has been observed among SLE cases compared to controls [107], while a controversial study by Pellet et al. has observed the absence of KIR2DS2 in SLE cases (Table 2) [108]. Since KIR2DL2 has been associated to increased susceptibility to herpetic infections [97], the presence of this KIR gene may represent a common feature for SLE development in the presence of herpesvirus infections (Table 2).

A recent clinical study has evaluated the involvement of KIR genes in Rheumatoid Arthritis (RA), in the presence of EBV and HCMV infections. The study found that the presence of activating KIR2DS2 and inhibitory KIR2DL3 receptors, in the presence of EBV and HCMV infections, might be associated with a worst RA prognosis [109] (Table 2).

EBV encode an miRNA that targets MICB, miR-BART2-5p, resulting in reduced NK cell-mediated killing (Table 2) $[93,173]$. Moreover, in the specific case of EBV infection, KIR2DS5 and KIR2DS4 were associated with increased risk of lymphoproliferative diseases (Table 2) [110].

Human Herpesvirus 8 (HHV-8), also called Kaposi's Sarcoma-associated Herpesvirus (KSHV), exploits an immune-escape mechanism consisting in the acceleration of HLA-I molecule endocytosis which involves K3 and K5 viral proteins (Figure 7). Interestingly, K3 downregulates the expression of both canonical and non-canonical HLA class I molecules in humans (HLA-A, -B, -C, and -E), whereas K5 primarily downregulates HLA-A and -B alleles (Table 2) [111-113]. HHV-8 infection is notably associated to autoimmune and neoplastic disorders and KIRs profile seems to play a role in the development of correlated diseases. In particular, HHV-8 infected type-2 diabetes subjects showed an increased frequency of KIR2DL2/HLA-C1 pair in comparison with uninfected patients (Table 2) [114], HHV8 positive cutaneous vascular lesions were significantly associated with KIR2DL2/DS2 homozygosity (Table 2) [115], and patients affected by classic Kaposi Sarcoma, typically positive for HHV-8 infection, showed a higher frequency of KIR2DS1 and KIR3DS1 compared to controls (Table 2) [116].

Human Herpes Virus-6 (HHV-6) susceptibility association to peculiar KIR \HLA-I expression has been widely described. HHV-6 has been recently distinguished in two different viruses, HHV-6A and -6B, characterized by different biological features [123]. In particular, while HHV-6B tropism is more aimed at T cells, HHV-6A is able to infect a wide range of tissues and differently affects NK cell activation. This peculiarity involves a differential viral DNA sensing [118] and KIRs modulation and leads to a mechanism of anti-viral activation, characterized by a Th2 type response and a non-cytotoxic profile. HHV-6A infection induced PKA activity and phosphorylation of Sp1 in the NK cells, which may increase expression of KIR2DL2 and thereby inhibit NK cell cytotoxicity (Figure 7). These findings were reported associated to Alzheimer's Disease (AD), where the authors noted that the HHV-6A-induced expression of apolipoprotein E e4, a known marker for AD, may further inhibit NK cell function, in part by increasing PKA activity, Tau hyperphosphorylation, and amyloid-beta deposition (Table 2) [117].

Herpesviruses, and in particular HHV-6, were found to have a possible association with neural pathologies because of their peculiar neurotropism and the ability to establish latent infections [174], as supported also by the presence of HHV-6 infection in AD post-mortem brain tissue $[175,176]$ and in Multiple Sclerosis (MS) plaques $[177,178]$. The increased susceptibility to herpesviruses infection in neurological subjects seems to be associated to KIR2DL2/HLA-C1 expression on the surface of NK cells in both AD and MS patients $[118,119]$. This was confirmed by the evidence that patients expressing KIR2DL2 are characterized by impaired NK cells response against herpesviruses, favoring the in- 
fection and possibly disease outcome $[97,118]$. The ability of herpesviruses to establish a lifelong latency in CNS, with the potential to reactivate, suggests these viruses as co-factors in the relapsing-remitting course of MS, particularly in association to KIR2DL2 presence, since KIR2DL2 expression on NK cells enhances viral reactivations, concomitantly with the typical relapses of the disease (Table 2) [120]. HHV-6 infection and KIRs are also possibly implicated in reproductive pathologies, including intrauterine growth restriction (IUGR) and infertility.

One of the most important KIRs expressed mostly on dNK cells is KIR2DL4. This receptor is engaged by HLA-G expressing trophoblast cells during placental development, where it triggers vascular remodeling. Its role during placentation is supported by the highest KIR2DL4 gene expression in healthy pregnant women compared to patients with recurrent spontaneous miscarriage [179]. In IUGR placentas, HHV-6 infection has been reported together with increased HLA-G expression which possibly affect $\mathrm{dNK}$ cell function engaging KIR2DL4 (Table 2) [121,123]. It was suggested that this effect on HLA-G expression and might be due the expression the U94 viral protein [122] (Figure 7). Moreover, the presence of HHV-6A infection in endometrial cells was reported to be associated with primary idiopathic infertility in women [123-126], together with altered basal sHLA-G levels and $\mathrm{CD} 56^{+} \mathrm{KIR} 2 \mathrm{DL} 4^{+}$endometrial NK cell percentages (Table 2) [127]. Furthermore, HHV6 endometrial infection in idiopathic infertile women seems to be correlated to the presence of the inhibitory receptor KIR2DL2, while, on the contrary, the inhibitory receptor KIR2DL5 was found with lower frequency in comparison to the fertile cohort (Table 2) [128].

The possible implication of KIR2DL2 in infertility in presence of herpetic infections was also confirmed by El Borai et al., who reported the association between Herpes simplex virus (HSV)-1 and male infertility. The authors found HSV-1 DNA in $24 \%$ of semen samples obtained from infertile males [129], in correspondence to high frequency of KIR2DL2/HLAC combination, compared to healthy controls (Table 2) [130].

\subsection{Human Immunodeficiency Virus (HIV)}

Concerning HIV infection, HLA/KIR combinations have been associated with virusassociated disease progression and protection against disease acquisition. The mechanisms conferring this protection may include the direct interaction of KIRs with HIV-derived peptide motifs presented on HLA molecules and confirmed by in vitro experiments reporting that specific viral variant/KIR combinations associate with differences in NK cell viral inhibition [23] and that distinct HLA/KIR combinations confer differences in HIV control [180] and susceptibility [141,181]. In particular, KIR2DL5 and KIR2DS5 have been associated with decreased odds of HIV transmission [95], in concordance with a study on cell surface expression levels of all common HLA-C allotypes in African and European Americans [131], which reported an increased HLA-C expression associated with protection from infection (Table 2).

HIV has the distinctive ability to selectively downregulate HLA-A and HLA-B on the surface of infected cells through Nef protein (Figure 7; Table 2), without affecting HLA-C and HLA-E expression [133], controlling in this way both CTL and NK cell activation. To disrupt the cell surface expression of HLA-A and HLA-B molecules, Nef binds to the cytoplasmic tail domain and promotes the association of the conserved HLA-I cytoplasmic tail tyrosine residue with the clathrin adaptor protein 1 (AP-1) [182,183]. Significantly, HLA$\mathrm{C}$ cytoplasmic tails lack two amino acids necessary for this interaction. As a result, the HIV-1 Nef protein does not downmodulate HLA-C molecules from the cell surface (Table 2) [132].

Besides Nef protein, also HIV Gag and Env proteins participate in NK cell regulation via KIRs engagement by modulating HLA-C expression (Figure 7).

Fedda et al. identified one HLA-Cw*0102-presented peptide (p24 Gag209-218) that was recognized by the inhibitory NK cell receptor KIR2DL2 leading to functional inhibition of KIR2DL2-expressing NK cells, suggesting that selections of sequence polymorphisms that increase avidity to KIR2DL2 might provide a mechanism for HIV-1 to escape NK cell-mediated immune pressure (Table 2) [134]. 
Again, it was found that the presence of HLA-C, particularly as free heavy chains, positively modulates the infectivity of HIV-1 [135] as a result of the association with HIV-1 Env protein at the cell membrane level [136]. This work suggested that HIV-1 envelope may facilitate dissociation of $\beta 2 \mathrm{M}$ from HLA-C, leading to higher levels of HLA-C free chain molecules at the cell surface influencing HIV-1 infectivity.

HIV infection is notably associated to pregnancy problems, due to viral-related immune system dysfunctions [184] and the role of KIRs concerning HIV mother-child transmission during pregnancy has been investigated. In particular, KIR3DS1 has been associated with higher NK cells effector functions in early HIV-1 disease, which may lead to better clinical outcomes reducing perinatal transmission (Table 2) [137,138]. In addition, KIR3DL1, KIR2DL2, KIR2DL3, KIR2DL5, KIR2DS5, and HLA-C ligands were associated with newborn protection against HIV-1 infection (Table 2) [139,140].

On the contrary, KIR2DL2, KIR2DS2, KIR2DS3, KIR2DS4, KIR3DS1 receptors have been associated with higher susceptibility to HIV-1 infection in the child (Table 2) [138].

A role for HIV infection in immune disorders has also been described in association with particular KIRs.

HIV positive patients expressing KIR3DS1 and HLA-Bw4-80I showed a decrease AIDS (Acquired Immune Deficiency Syndrome) progression, compared to KIR3DS1 and HLA-Bw4-80I negative subjects [141], possibly due to a protective effect toward HIV infection [142]. In individuals infected with HIV, this effect is confirmed by a lower viral load and the protection against opportunistic infections [185,186]. Moreover, a study conducted on HIV exposed intravenous drug users from Vietnam showed an increased KIR3DS1 homozygosity and a high prevalence of B haplotypes in HIV exposed seronegative intravenous drug users $[143,144]$ which could explain the resistance to HIV infection observed in these subjects (Table 2).

\subsection{Hepatitis Viruses ( $H B V$ and $H C V$ )}

Hepatitis B virus (HBV) and hepatitis C virus (HCV) account for $70 \%$ of the global burden of liver disease [187], often involved in neoplastic transformation processes. The clinical outcomes following infection with both HBV and HCV viruses vary considerably, from clearance of infection to chronic viral persistence, cirrhosis, and hepatocellular carcinoma (HCC) [188]. Since the interaction between virus and immune system plays an important role in pathogenesis, inflammation, necrosis, and fibrosis of the liver tissue [189], different candidate gene association studies have identified specific immune receptors associations for both HBV and HCV susceptibility and outcome. Among these receptors, specific KIR genes have been reported to affect the immune response against viral infections in liver.

Liver NK cells show phenotypic and functional characteristics that are distinct from their circulating counterparts. In particular, even if the majority of intrahepatic NK cells have a CD56 $6^{\text {bright }}$ phenotype, their $\mathrm{CD} 56^{\text {dim }} \mathrm{CD} 16^{+}$fraction express lower levels of KIRs than NK cell subset in the periphery, which may limit their capacity to be adequately licensed [190].

This hepatic NK cell enrichment is maintained in the inflammatory infiltrate characteristic of HBV infection. In fact, in order to understand the role of NK cells in HBV infection it is necessary to first consider the liver microenvironment, well known for its tolerogenic properties due to the local immunological environment including the cytokine and nutrient milieu [191,192]. For example, Kupffer cells are able to produce immunosuppressive cytokines such as IL-10 and TGF- $\beta$ that can tolerize local intrahepatic NK cells also affecting HLA-I and stress ligands expression $[193,194]$. These modulations, together with KIRs profile, participate in infection resolution and outcome.

A genetic tendency towards lower activation of NK cells in HBV recovered subjects was described in presence of activating KIRs-phenotype, characterized, for example, by KIR2DS1, KIR2DS2 expression, during HBV infection (Table 2) [145]. Other studies reported that KIR2DL3/HLA-C1 homozygosity is protective toward susceptibility to HBV infection, 
while KIR2DL1/HLA-C2 is associated to high HBV infection rate (Table 2) [146]. In addition, KIR2DS2 and KIR2DS3 act as HBV susceptibility genes in the presence of chronic hepatitis B, whereas KIR2DS1, KIR3DS1, and KIR2DL5 may be protective genes facilitating the clearance of HBV, consequently protecting from cancer development (Table 2) [148].

This latter evidence was supported also by a study on a Turkish cohort that showed a higher rate of inhibitory KIR2DL3 and KIR3DS1 in the healthy group than in the group composed of chronic HBV patients and patients with spontaneous remission [149]. Moreover, a case-control study showed that HLA-C1 was associated with disease progression towards hepatocellular carcinoma (HCC) in HBV-infected patients (Table 2). In particular, one copy of HLA-C1 alleles was associated with cirrhosis, while two copies were associated with HCC (Table 2) [150].

In a later study, the frequencies of KIR and HLA genes were compared in subjects with chronic hepatitis B (CHB) and subjects with resolved infection [147]. Once again, the inhibitory KIR2DL3 gene was less frequent in CHB (81\%) than in subjects with resolved infection (98\%), suggesting the protective role of this KIR in CHB development. Moreover, the authors found higher frequency of both HLA-C2 and HLA-A-Bw4 alleles in CHB group compared to subjects with resolved infection and controls (Table 2). No difference was reported in the frequency of KIR haplotypes between the groups, suggesting that activating receptors might do not play a role in controlling the infection. The results obtained by these studies suggest that KIR/HLA combination is able to predict the outcome of HBV infection and consequently cancer progression.

As well as HBV, HCV can exploit KIR receptors to modulate NK cell response [195], increasing viral spread and inducing the neoplastic process. Thus, KIR/HLA combination might influence $\mathrm{HCV}$ infection outcome, influencing $\mathrm{HCV}$ viral load and the risk of hepatocellular carcinoma progression $[159,196]$. NK cells were demonstrated to mediate the inhibition of HCV-replication and to exert a targeted cytotoxic action against infected cells $[197,198]$.

Several KIRs have been identified as relevant to the outcome of HCV infection and treatment efficacy, including KIR2DL2, KIR2DL3, KIR2DL1, KIR2DS2, and KIR3DL1, together with HLA-C2 expression (Table 2) [151,152].

In particular, Lunemann and coauthors identified a core-derived epitope that dampens NK cell responses, and thereby possibly prevents killing of infected cells through this part of the innate immune system. This 9mer HCV peptide, YIPLVGAPL, is facilitated via presentation of the viral peptide on HLA-C $* 03: 04$ to the inhibitory KIR receptor KIR2DL3 on NK cells [153]. In fact, this HCV peptide resulted in significantly higher KIR2DL3 binding to HLA-C $* 03: 04$ suggesting that HCV genotype 1 binding to HLA-C $* 03: 04$ results in a sequence-dependent engagement of the inhibitory NK cell receptor KIR2DL3, showing that sequence variations within $\mathrm{HCV}$ can modulate NK cell function, providing potential pathways for viral escape (Figure 7; Table 2).

Another strategy used in HCV escape consists in mutations at the HLA-B*27 binding anchor of the epitope [154]. This epitope is present in the viral RNA-dependent RNA polymerase. The ability to mutate at the main HLA-B*27-binding anchor is dependent on viral fitness [199]. Misfolded HLA-B*27 may also be unable to engage KIR3DL1, resulting in increased NK cell activation (Table 2) $[155,156]$. Moreover, another study reported that the expression of KIR3DL1 was decreased in individuals with HCV infection, supporting the role of this receptor in the regulation of chronic HCV infection (Table 2) [157].

HCV patients were found with high frequency of KIR2DS3 receptor [158] and a protective role for HLA-Bw4/KIR3DS1 against liver disease progression has been also proposed (Table 2) [159].

Another study has shown that KIR2DL3 was associated with spontaneous resolution of HCV infection, in presence of HLA-C1 homozygous genotype [160]. At the same time, HLA-C1/KIR2DL3 has also been associated with sustained virus response to anti-HCV therapy (Table 2), even if previous data have also suggested that KIR2DL1/HLA-C2 combination may confer stronger inhibitory responses than KIR2DL3/HLA-C1 [161]. 


\subsection{Other Viruses}

In addition, other viral infections have been reported to be associated to characteristic KIRs asset, including enterovirus, Parvoviruses, and Human Papillomavirus (HPV).

Enteroviruses represent risk factors for T1D and have been reportedly associated to peculiar KIRs [171]; enteroviruses have been reported to possibly directly affect pancreatic islets, together with low expression level of the inhibitory receptor KIR3DL1, in TD1 patients (Table 2) [162].

Hashimoto's Thyroiditis (HT) is another autoimmune disease in which an increased susceptibility to enterovirus was reported [163], in association with upregulation of HLA-I molecules (Table 2). The colocalization of HLA class I with STAT1 and VP1 with PKR indicates an intracellular, antiviral host response, supporting a firm link between viral infection and autoimmune thyroid diseases which possibly also affects NK cell function via KIRs engagement.

Parvovirus 9, similarly to CMV and HCV, have been reported implicated in SLE susceptibility [171], possibly in concomitance to the presence of KIR2DL2 and KIR2DS1 (Table 2) $[107,172]$. In addition, Parvovirus B19 has been reported in SLE to be responsible for an aberrant immune activation [164] involving HLA molecules upregulation which allows a persistent viral infection (Table 2) [165].

HPV infection is known to be the main risk factor for the development of premalignant and malignant epithelial lesions of the cervix [200]. Besides HPV infection, there are other factors participating in increasing cervix cancer susceptibility. Rizzo et al. demonstrated that KIR2DL2/HLA-C1 and KIR2DL3/HLA-C1 pairs constitute a risk factors for HPV high-risk infection, while the increased frequency of HLA-C2 alleles in HPV-positive patients did not increase risk [166]. In this study, HPV-positive subjects with cervix cancer presented a decreased KIR2DL2/HLA-C2 frequency, while KIR2DL1 was found in most of the subjects. In particular, it has been hypothesized that KIR2DL2/HLA-C1 and KIR2DL3/HLA-C1 presence could induce NK cells inhibition toward HPV infection, sustaining the high-risk HPV-associated transformation and the development of pre-neoplastic lesions (Table 2) [166].

\section{Conclusions}

The role of NK cells in controlling viral infection is known and the efficiency in the control of viral spread and host outcomes is due to the crosstalk between intracellular signals received from a large repertoire of germ-line-encoded surface receptors.

Among NK receptors, the family of killer immunoglobulin-like receptors (KIR) is characterized by highly polymorphic activating and inhibitory receptors, involved in the regulation of NK cell functions. Specific ligands for KIRs are Human Leukocyte Antigen (HLA) molecules expressed on target cells, whose binding induces NK cells activation/inhibition.

In this review we have reported the role of KIR receptors in viral infection control by NK cells. In particular, we reported several strategies developed by viruses to alter NK cell activation affecting KIRs/ligands expression (Figure 7) and that peculiar KIR assets have been found possibly correlated to viral infection susceptibility and human disease development and progression.

In conclusion, the crucial role of KIRs in the control of viral infection suggests these receptors, together with their ligands, as possible targets for new therapeutical strategies for viral infections' clearance and as putative biomarkers for disease prognosis.

Author Contributions: Conceptualization, D.B. and R.R.; data curation, S.R., G.S. and S.B.; writingoriginal draft, S.R., V.G. and G.S.; writing—review and editing, D.B. and R.R.; supervision, D.B.; funding acquisition, R.R. All authors have read and agreed to the published version of the manuscript.

Funding: This work was supported by FISM-Fondazione Italiana Sclerosi Multipla grant (cod 2015/R/20; 2020-FOND-RR_001 to R.R.).

Institutional Review Board Statement: Not applicable. 
Informed Consent Statement: Not applicable.

Data Availability Statement: Not applicable.

Conflicts of Interest: None of the authors have any conflicts of interest in association with this manuscript.

\section{References}

1. Lanier, L.L. NK cell recognition. Annu. Rev. Immunol. 2005, 23, 225-274. [CrossRef] [PubMed]

2. Sojka, D.K.; Tian, Z.; Yokoyama, W.M. Tissue-resident natural killer cells and their potential diversity. In Seminars in Immunology; Academic Press: Cambridge, MA, USA, 2014; pp. 127-131.

3. Yokoyama, W.M.; Sojka, D.K.; Peng, H.; Tian, Z. Tissue-resident natural killer cells. In Cold Spring Harbor Symposia on Quantitative Biology; Cold Spring Harbor Laboratory Press: Long Island, NY, USA, 2013; pp. 149-156.

4. Poli, A.; Michel, T.; Theresine, M.; Andres, E.; Hentges, F.; Zimmer, J. CD56bright natural killer (NK) cells: An important NK cell subset. Immunology 2009, 126, 458-465. [CrossRef] [PubMed]

5. Ferlazzo, G.; Thomas, D.; Lin, S.L.; Goodman, K.; Morandi, B.; Muller, W.A.; Moretta, A.; Munz, C. The Abundant Nk Cells in human secondary lymphoid tissues require activation to express killer cell Ig-like receptors and become cytolytic. J. Immunol. 2004, 172, 1455-1462. [CrossRef]

6. Perussia, B.; Chen, Y.; Loza, M.J. Peripheral NK cell phenotypes: Multiple changing of faces of an adapting, developing cell. Mol. Immunol. 2005, 42, 385-395. [CrossRef] [PubMed]

7. Loke, Y.; King, A. Human Implantation: Cell Biology and Immunology; Cambridge University Press: Cambridge, UK, 1995.

8. Moffett-King, A. Natural killer cells and pregnancy. Nat. Rev. Immunol. 2002, 2, 656-663. [CrossRef] [PubMed]

9. Moffett-King, A.; Entrican, G.; Ellis, S.; Hutchinson, J.; Bainbridge, D. Natural killer cells and reproduction. Trends Immunol. 2002, 23, 332-333. [CrossRef]

10. Biron, C.A.; Brossay, L. NK cells and NKT cells in innate defense against viral infections. Curr. Opin. Immunol. 2001, 13, 458-464. [CrossRef]

11. Schmeel, L.C.; Schmeel, F.C.; Coch, C.; Schmidt-Wolf, I.G. Cytokine-induced killer (CIK) cells in cancer immunotherapy: Report of the international registry on CIK cells (IRCC). J. Cancer Res. Clin. Oncol. 2015, 141, 839-849. [CrossRef]

12. Li, Y.; Schmidt-Wolf, I.G.; Wu, Y.F.; Huang, S.L.; Wei, J.; Fang, J.; Huang, K.; Zhou, D.H. Optimized protocols for generation of cord blood-derived cytokine-induced killer/natural killer cells. Anticancer Res. 2010, 30, 3493-3499.

13. Cooper, M.A.; Fehniger, T.A.; Caligiuri, M.A. The biology of human natural killer-cell subsets. Trends Immunol. 2001, 22, 633-640. [CrossRef]

14. Kumar, S. Natural killer cell cytotoxicity and its regulation by inhibitory receptors. Immunology 2018, 154, 383-393. [CrossRef] [PubMed]

15. Mavilio, D.; Benjamin, J.; Daucher, M.; Lombardo, G.; Kottilil, S.; Planta, M.A.; Marcenaro, E.; Bottino, C.; Moretta, L.; Moretta, A.; et al. Natural killer cells in HIV-1 infection: Dichotomous effects of viremia on inhibitory and activating receptors and their functional correlates. Proc. Natl. Acad. Sci. USA 2003, 100, 15011-15016. [CrossRef] [PubMed]

16. Alter, G.; Teigen, N.; Davis, B.T.; Addo, M.M.; Suscovich, T.J.; Waring, M.T.; Streeck, H.; Johnston, M.N.; Staller, K.D.; Zaman, M.T.; et al. Sequential deregulation of NK cell subset distribution and function starting in acute HIV-1 infection. Blood 2005, 106, 3366-3369. [CrossRef]

17. Peritt, D.; Robertson, S.; Gri, G.; Showe, L.; Aste-Amezaga, M.; Trinchieri, G. Cutting edge: Differentiation of human NK cells into NK1 and NK2 subsets. J. Immunol. 1998, 161, 5821-5824.

18. Berahovich, R.D.; Lai, N.L.; Wei, Z.; Lanier, L.L.; Schall, T.J. Evidence for NK cell subsets based on chemokine receptor expression. J. Immunol. 2006, 177, 7833-7840. [CrossRef]

19. Michel, M.L.; Keller, A.C.; Paget, C.; Fujio, M.; Trottein, F.; Savage, P.B.; Wong, C.H.; Schneider, E.; Dy, M.; Leite-de-Moraes, M.C. Identification of an IL-17-producing NK1.1(neg) iNKT cell population involved in airway neutrophilia. J. Exp. Med. 2007, 204, 995-1001. [CrossRef]

20. Pandya, A.D.; Al-Jaderi, Z.; Hoglund, R.A.; Holmoy, T.; Harbo, H.F.; Norgauer, J.; Maghazachi, A.A. Identification of human NK17/NK1 cells. PLoS ONE 2011, 6, e26780. [CrossRef] [PubMed]

21. Rizzo, R.; Bortolotti, D.; Fainardi, E.; Gentili, V.; Bolzani, S.; Baldi, E.; Casetta, I.; Granieri, E.; Rotola, A.; Furlan, R.; et al. KIR2DL2 inhibitory pathway enhances Th17 cytokine secretion by NK cells in response to herpesvirus infection in multiple sclerosis patients. J. Neuroimmunol. 2016, 294, 1-5. [CrossRef] [PubMed]

22. Hou, W.; Kang, H.S.; Kim, B.S. Th17 cells enhance viral persistence and inhibit T cell cytotoxicity in a model of chronic virus infection. J. Exp. Med. 2009, 206, 313-328. [CrossRef]

23. Jost, S.; Altfeld, M. Control of human viral infections by natural killer cells. Annu. Rev. Immunol. 2013, 31, 163-194. [CrossRef]

24. Sun, J.C.; Lopez-Verges, S.; Kim, C.C.; DeRisi, J.L.; Lanier, L.L. NK cells and immune "memory". J. Immunol. 2011, $186,1891-1897$. [CrossRef]

25. Altfeld, M.; Fadda, L.; Frleta, D.; Bhardwaj, N. DCs and NK cells: Critical effectors in the immune response to HIV-1. Nat. Rev. Immunol. 2011, 11, 176-186. [CrossRef] [PubMed] 
26. Vivier, E.; Tomasello, E.; Baratin, M.; Walzer, T.; Ugolini, S. Functions of natural killer cells. Nat. Immunol. 2008, 9, 503-510. [CrossRef] [PubMed]

27. Biron, C.A.; Byron, K.S.; Sullivan, J.L. Severe herpesvirus infections in an adolescent without natural killer cells. N. Engl. J. Med. 1989, 320, 1731-1735. [CrossRef] [PubMed]

28. Orange, J.S. Human natural killer cell deficiencies and susceptibility to infection. Microbes Infect. 2002, 4, 1545-1558. [CrossRef]

29. Biron, C.A.; Dalod, M.; Salazar-Mather, T.P. Innate immunity and viral infections. Immunol. Infect. Dis. 2001, 11, 139-160. [CrossRef]

30. Solerte, S.B.; Cravello, L.; Ferrari, E.; Fioravanti, M. Overproduction of IFN-gamma and TNF-alpha from natural killer (NK) cells is associated with abnormal NK reactivity and cognitive derangement in Alzheimer's disease. Ann. N. Y. Acad. Sci. 2000, 917, 331-340. [CrossRef]

31. Fehniger, T.A.; Cooper, M.A.; Nuovo, G.J.; Cella, M.; Facchetti, F.; Colonna, M.; Caligiuri, M.A. CD56bright natural killer cells are present in human lymph nodes and are activated by T cell-derived IL-2: A potential new link between adaptive and innate immunity. Blood 2003, 101, 3052-3057. [CrossRef]

32. Walzer, T.; Dalod, M.; Robbins, S.H.; Zitvogel, L.; Vivier, E. Natural-killer cells and dendritic cells: "l'union fait la force". Blood 2005, 106, 2252-2258. [CrossRef]

33. Long, E.O. Ready for prime time: NK cell priming by dendritic cells. Immunity 2007, 26, 385-387. [CrossRef]

34. Sim, G.C.; Radvanyi, L. The IL-2 cytokine family in cancer immunotherapy. Cytokine Growth Factor Rev. 2014, 25, 377-390. [CrossRef]

35. Giri, J.G.; Kumaki, S.; Ahdieh, M.; Friend, D.J.; Loomis, A.; Shanebeck, K.; DuBose, R.; Cosman, D.; Park, L.S.; Anderson, D.M. Identification and cloning of a novel IL-15 binding protein that is structurally related to the alpha chain of the IL-2 receptor. EMBO J. 1995, 14, 3654-3663. [CrossRef]

36. Fehniger, T.A.; Shah, M.H.; Turner, M.J.; VanDeusen, J.B.; Whitman, S.P.; Cooper, M.A.; Suzuki, K.; Wechser, M.; Goodsaid, F.; Caligiuri, M.A. Differential cytokine and chemokine gene expression by human NK cells following activation with IL-18 or IL-15 in combination with IL-12: Implications for the innate immune response. J. Immunol. 1999, 162, 4511-4520.

37. Lucas, M.; Schachterle, W.; Oberle, K.; Aichele, P.; Diefenbach, A. Dendritic cells prime natural killer cells by trans-presenting interleukin 15. Immunity 2007, 26, 503-517. [CrossRef]

38. Nandagopal, N.; Ali, A.K.; Komal, A.K.; Lee, S.H. The critical role of IL-15-PI3K-mTOR pathway in natural killer cell effector functions. Front. Immunol. 2014, 5, 187. [CrossRef] [PubMed]

39. Fehniger, T.A.; Cai, S.F.; Cao, X.; Bredemeyer, A.J.; Presti, R.M.; French, A.R.; Ley, T.J. Acquisition of murine NK cell cytotoxicity requires the translation of a pre-existing pool of granzyme B and perforin mRNAs. Immunity 2007, 26, 798-811. [CrossRef]

40. Cooper, M.A.; Elliott, J.M.; Keyel, P.A.; Yang, L.; Carrero, J.A.; Yokoyama, W.M. Cytokine-induced memory-like natural killer cells. Proc. Natl. Acad. Sci. USA 2009, 106, 1915-1919. [CrossRef] [PubMed]

41. Zamai, L.; Ahmad, M.; Bennett, I.M.; Azzoni, L.; Alnemri, E.S.; Perussia, B. Natural killer (NK) cell-mediated cytotoxicity: Differential use of TRAIL and Fas ligand by immature and mature primary human NK cells. J. Exp. Med. 1998, 188, 2375-2380. [CrossRef]

42. Bryceson, Y.T.; Chiang, S.C.; Darmanin, S.; Fauriat, C.; Schlums, H.; Theorell, J.; Wood, S.M. Molecular mechanisms of natural killer cell activation. J. Innate Immun. 2011, 3, 216-226. [CrossRef]

43. Lanier, L.L. Up on the tightrope: Natural killer cell activation and inhibition. Nat. Immunol. 2008, 9, 495-502. [CrossRef]

44. Veillette, A. SLAM-family receptors: Immune regulators with or without SAP-family adaptors. Cold Spring Harb. Perspect. Biol. 2010, 2, a002469. [CrossRef]

45. $\mathrm{Wu}, \mathrm{N}$.; Veillette, A. SLAM family receptors in normal immunity and immune pathologies. Curr. Opin. Immunol. 2016, 38, 45-51. [CrossRef] [PubMed]

46. Cerwenka, A.; Lanier, L.L. Natural killer cell memory in infection, inflammation and cancer. Nat. Rev. Immunol. 2016, 16, 112-123. [CrossRef] [PubMed]

47. Afonina, I.S.; Cullen, S.P.; Martin, S.J. Cytotoxic and non-cytotoxic roles of the CTL/NK protease granzyme B. Immunol. Rev. 2010, 235, 105-116. [CrossRef] [PubMed]

48. Arnon, T.I.; Markel, G.; Mandelboim, O. Tumor and viral recognition by natural killer cells receptors. In Seminars in Cancer Biology; Academic Press: Cambridge, MA, USA, 2006; pp. 348-358.

49. Jost, S.; Altfeld, M. Evasion from NK cell-mediated immune responses by HIV-1. Microbes Infect. 2012, 14, 904-915. [CrossRef]

50. Arnon, T.I.; Lev, M.; Katz, G.; Chernobrov, Y.; Porgador, A.; Mandelboim, O. Recognition of viral hemagglutinins by NKp44 but not by NKp30. Eur. J. Immunol. 2001, 31, 2680-2689. [CrossRef]

51. Mandelboim, O.; Lieberman, N.; Lev, M.; Paul, L.; Arnon, T.I.; Bushkin, Y.; Davis, D.M.; Strominger, J.L.; Yewdell, J.W.; Porgador, A. Recognition of haemagglutinins on virus-infected cells by NKp46 activates lysis by human NK cells. Nature 2001, 409, 1055-1060. [CrossRef]

52. Baugh, R.; Khalique, H.; Seymour, L.W. Convergent evolution by cancer and viruses in evading the NKG2D immune response. Cancers 2020, 12, 3827. [CrossRef] [PubMed] 
53. Sun, H.; Sun, C. The rise of NK cell checkpoints as promising therapeutic targets in cancer immunotherapy. Front. Immunol. 2019, 10, 2354. [CrossRef] [PubMed]

54. Campbell, K.S.; Purdy, A.K. Structure/function of human killer cell immunoglobulin-like receptors: Lessons from polymorphisms, evolution, crystal structures and mutations. Immunology 2011, 132, 315-325. [CrossRef] [PubMed]

55. Pende, D.; Falco, M.; Vitale, M.; Cantoni, C.; Vitale, C.; Munari, E.; Bertaina, A.; Moretta, F.; Del Zotto, G.; Pietra, G.; et al. Killer Ig-like receptors (KIRs): Their role in NK cell modulation and developments leading to their clinical exploitation. Front. Immunol. 2019, 10, 1179. [CrossRef] [PubMed]

56. Colonna, M.; Samaridis, J. Cloning of immunoglobulin-superfamily members associated with HLA-C and HLA-B recognition by human natural killer cells. Science 1995, 268, 405-408. [CrossRef] [PubMed]

57. D'Andrea, A.; Chang, C.; Franz-Bacon, K.; McClanahan, T.; Phillips, J.H.; Lanier, L.L. Molecular cloning of NKB1. A natural killer cell receptor for HLA-B allotypes. J. Immunol. 1995, 155, 2306-2310. [PubMed]

58. Scharenberg, A.M.; Kinet, J.P. The emerging field of receptor-mediated inhibitory signaling: SHP or SHIP? Cell 1996, 87, 961-964. [CrossRef]

59. Rajagopalan, S.; Fu, J.; Long, E.O. Cutting edge: Induction of IFN-gamma production but not cytotoxicity by the killer cell Ig-like receptor KIR2DL4 (CD158d) in resting NK cells. J. Immunol. 2001, 167, 1877-1881. [CrossRef]

60. Kikuchi-Maki, A.; Catina, T.L.; Campbell, K.S. Cutting edge: KIR2DL4 transduces signals into human NK cells through association with the fc receptor gamma protein. J. Immunol. 2005, 174, 3859-3863. [CrossRef] [PubMed]

61. Binstadt, B.A.; Brumbaugh, K.M.; Dick, C.J.; Scharenberg, A.M.; Williams, B.L.; Colonna, M.; Lanier, L.L.; Kinet, J.P.; Abraham, R.T.; Leibson, P.J. Sequential involvement of Lck and SHP-1 with MHC-recognizing receptors on NK cells inhibits FcR-initiated tyrosine kinase activation. Immunity 1996, 5, 629-638. [CrossRef]

62. Valiante, N.M.; Phillips, J.H.; Lanier, L.L.; Parham, P. Killer cell inhibitory receptor recognition of human leukocyte antigen (HLA) class I blocks formation of a pp36/PLC-gamma signaling complex in human natural killer (NK) cells. J. Exp. Med. 1996, 184, 2243-2250. [CrossRef]

63. Pegram, H.J.; Andrews, D.M.; Smyth, M.J.; Darcy, P.K.; Kershaw, M.H. Activating and inhibitory receptors of natural killer cells. Immunol. Cell Biol. 2011, 89, 216-224. [CrossRef]

64. Jonsson, A.H.; Yokoyama, W.M. Natural killer cell tolerance licensing and other mechanisms. Adv. Immunol. 2009, 101, 27-79. [CrossRef] [PubMed]

65. Carey, B.S.; Poulton, K.V.; Poles, A. Factors affecting HLA expression: A review. Int. J. Immunogenet. 2019, 46, 307-320. [CrossRef]

66. Van den Elsen, P.J. Expression regulation of major histocompatibility complex class I and class II encoding genes. Front. Immunol. 2011, 2, 48. [CrossRef]

67. Van den Elsen, P.J.; Holling, T.M.; Kuipers, H.F.; van der Stoep, N. Transcriptional regulation of antigen presentation. Curr. Opin. Immunol. 2004, 16, 67-75. [CrossRef]

68. Stewart, C.A.; Laugier-Anfossi, F.; Vely, F.; Saulquin, X.; Riedmuller, J.; Tisserant, A.; Gauthier, L.; Romagne, F.; Ferracci, G.; Arosa, F.A.; et al. Recognition of peptide-MHC class I complexes by activating killer immunoglobulin-like receptors. Proc. Natl. Acad. Sci. USA 2005, 102, 13224-13229. [CrossRef] [PubMed]

69. Dohring, C.; Colonna, M. Human natural killer cell inhibitory receptors bind to HLA class I molecules. Eur. J. Immunol. 1996, 26, 365-369. [CrossRef]

70. Pende, D.; Biassoni, R.; Cantoni, C.; Verdiani, S.; Falco, M.; di Donato, C.; Accame, L.; Bottino, C.; Moretta, A.; Moretta, L. The natural killer cell receptor specific for HLA-A allotypes: A novel member of the p58/p70 family of inhibitory receptors that is characterized by three immunoglobulin-like domains and is expressed as a 140-kD disulphide-linked dimer. J. Exp. Med. 1996, 184, 505-518. [CrossRef]

71. Tajik, N.; Shahsavar, F.; Mousavi, T.; Radjabzadeh, M.F. Distribution of KIR genes in the Iranian population. Tissue Antigens 2009, 74, 22-31. [CrossRef] [PubMed]

72. Martin, A.M.; Kulski, J.K.; Gaudieri, S.; Witt, C.S.; Freitas, E.M.; Trowsdale, J.; Christiansen, F.T. Comparative genomic analysis, diversity and evolution of two KIR haplotypes A and B. Gene 2004, 335, 121-131. [CrossRef] [PubMed]

73. Gomez-Lozano, N.; Estefania, E.; Williams, F.; Halfpenny, I.; Middleton, D.; Solis, R.; Vilches, C. The silent KIR3DP1 gene (CD158c) is transcribed and might encode a secreted receptor in a minority of humans, in whom the KIR3DP1, KIR2DL4 and KIR3DL1/KIR3DS1 genes are duplicated. Eur. J. Immunol. 2005, 35, 16-24. [CrossRef]

74. Gomez-Lozano, N.; Gardiner, C.M.; Parham, P.; Vilches, C. Some human KIR haplotypes contain two KIR2DL5 genes: KIR2DL5A and KIR2DL5B. Immunogenetics 2002, 54, 314-319. [CrossRef]

75. Uhrberg, M. The KIR gene family: Life in the fast lane of evolution. Eur. J. Immunol. 2005, 35, 10-15. [CrossRef]

76. Uhrberg, M.; Valiante, N.M.; Shum, B.P.; Shilling, H.G.; Lienert-Weidenbach, K.; Corliss, B.; Tyan, D.; Lanier, L.L.; Parham, P. Human diversity in killer cell inhibitory receptor genes. Immunity 1997, 7, 753-763. [CrossRef]

77. Shilling, H.G.; Guethlein, L.A.; Cheng, N.W.; Gardiner, C.M.; Rodriguez, R.; Tyan, D.; Parham, P. Allelic polymorphism synergizes with variable gene content to individualize human KIR genotype. J. Immunol. 2002, 168, 2307-2315. [CrossRef] 
78. Yawata, M.; Yawata, N.; Abi-Rached, L.; Parham, P. Variation within the human killer cell immunoglobulin-like receptor (KIR) gene family. Crit. Rev. Immunol. 2002, 22, 463-482. [CrossRef] [PubMed]

79. Hsu, K.C.; Liu, X.R.; Selvakumar, A.; Mickelson, E.; O'Reilly, R.J.; Dupont, B. Killer Ig-like receptor haplotype analysis by gene content: Evidence for genomic diversity with a minimum of six basic framework haplotypes, each with multiple subsets. J. Immunol. 2002, 169, 5118-5129. [CrossRef] [PubMed]

80. Orange, J.S.; Fassett, M.S.; Koopman, L.A.; Boyson, J.E.; Strominger, J.L. Viral evasion of natural killer cells. Nat. Immunol. 2002, 3, 1006-1012. [CrossRef] [PubMed]

81. Machold, R.P.; Wiertz, E.J.; Jones, T.R.; Ploegh, H. The HCMV gene products US11 and US2 differ in their ability to attack allelic forms of murine major histocompatibility complex (MHC) class I heavy chains. J. Exp. Med. 1997, 185, 363-366. [CrossRef] [PubMed]

82. Früh, K.; Gruhler, A.; Krishna, R.M.; Schoenhals, G.J. A comparison of viral immune escape strategies targeting the MHC class I assembly pathway. Immunol. Rev. 1999, 168, 157-166. [CrossRef]

83. Chan, H.-W.; Kurago, Z.B.; Stewart, C.A.; Wilson, M.J.; Martin, M.P.; Mace, B.E.; Carrington, M.; Trowsdale, J.; Lutz, C.T. DNA methylation maintains allele-specific KIR gene expression in human natural killer cells. J. Exp. Med. 2003, 197, 245-255. [CrossRef]

84. Milavetz, B.I.; Balakrishnan, L. Viral epigenetics. Methods Mol. Biol. 2015, 1238, 569-596. [CrossRef]

85. Blazkova, J.; Trejbalova, K.; Gondois-Rey, F.; Halfon, P.; Philibert, P.; Guiguen, A.; Verdin, E.; Olive, D.; Van Lint, C.; Hejnar, J. CpG methylation controls reactivation of HIV from latency. PLoS Pathog. 2009, 5, e1000554. [CrossRef]

86. Chan, H.W.; Miller, J.S.; Moore, M.B.; Lutz, C.T. Epigenetic control of highly homologous killer Ig-like receptor gene alleles. J. Immunol. 2005, 175, 5966-5974. [CrossRef] [PubMed]

87. Rajagopalan, S.; Long, E.O. Understanding how combinations of HLA and KIR genes influence disease. J. Exp. Med. 2005, 201, 1025-1029. [CrossRef]

88. Snyder, M.R.; Weyand, C.M.; Goronzy, J.J. The double life of NK receptors: Stimulation or co-stimulation? Trends Immunol. 2004, 25, 25-32. [CrossRef]

89. López-Botet, M.; Llano, M.; Ortega, M. Human cytomegalovirus and natural killer-mediated surveillance of HLA class I expression: A paradigm of host-pathogen adaptation. Immunol. Rev. 2001, 181, 193-202. [CrossRef]

90. Miller, J.S. Biology of Natural Killer Cells in Cancer and Infection: Miniseries/Special Article. Cancer Investig. 2002, 20, 405-419. [CrossRef]

91. Hopfensperger, K.; Richard, J.; Stürzel, C.M.; Bibollet-Ruche, F.; Apps, R.; Leoz, M.; Plantier, J.-C.; Hahn, B.H.; Finzi, A.; Kirchhoff, F. Convergent Evolution of HLA-C Downmodulation in HIV-1 and HIV-2. mBio 2020, 11, e00782-20. [CrossRef] [PubMed]

92. Jugovic, P.; Hill, A.M.; Tomazin, R.; Ploegh, H.; Johnson, D.C. Inhibition of major histocompatibility complex class I antigen presentation in pig and primate cells by herpes simplex virus type 1 and 2 ICP47. J. Virol. 1998, 72, 5076-5084. [CrossRef] [PubMed]

93. Tortorella, D.; Gewurz, B.E.; Furman, M.H.; Schust, D.J.; Ploegh, H.L. Viral subversion of the immune system. Annu. Rev. Immunol. 2000, 18, 861-926. [CrossRef]

94. Collins, K.L.; Chen, B.K.; Kalams, S.A.; Walker, B.D.; Baltimore, D. HIV-1 Nef protein protects infected primary cells against killing by cytotoxic T lymphocytes. Nature 1998, 391, 397-401. [CrossRef] [PubMed]

95. Kulkarni, S.; Martin, M.P.; Carrington, M. The Yin and Yang of HLA and KIR in human disease. In Seminars in Immunology; Academic Press: Cambridge, MA, USA, 2008; pp. 343-352.

96. Romero, V.; Azocar, J.; Zúñiga, J.; Clavijo, O.P.; Terreros, D.; Gu, X.; Husain, Z.; Chung, R.T.; Amos, C.; Yunis, E.J. Interaction of NK inhibitory receptor genes with HLA-C and MHC class II alleles in Hepatitis C virus infection outcome. Mol. Immunol. 2008, 45, 2429-2436. [CrossRef]

97. Rizzo, R.; Gentili, V.; Casetta, I.; Caselli, E.; De Gennaro, R.; Granieri, E.; Cassai, E.; Di Luca, D.; Rotola, A. Altered natural killer cells' response to herpes virus infection in multiple sclerosis involves KIR2DL2 expression. J. Neuroimmunol. 2012, $251,55-64$. [CrossRef]

98. Gewurz, B.E.; Wang, E.W.; Tortorella, D.; Schust, D.J.; Ploegh, H.L. Human cytomegalovirus US2 endoplasmic reticulum-lumenal domain dictates association with major histocompatibility complex class I in a locus-specific manner. J. Virol. 2001, 75, 5197-5204. [CrossRef] [PubMed]

99. Guma, M.; Angulo, A.; Lopez-Botet, M. NK cell receptors involved in the response to human cytomegalovirus infection. Curr. Top Microbiol. Immunol. 2006, 298, 207-223. [CrossRef] [PubMed]

100. Lanteri, M.; Giordanengo, V.; Hiraoka, N.; Fuzibet, J.G.; Auberger, P.; Fukuda, M.; Baum, L.G.; Lefebvre, J.C. Altered T cell surface glycosylation in HIV-1 infection results in increased susceptibility to galectin-1-induced cell death. Glycobiology 2003, 13, 909-918. [CrossRef]

101. Kielczewska, A.; Pyzik, M.; Sun, T.; Krmpotic, A.; Lodoen, M.B.; Munks, M.W.; Babic, M.; Hill, A.B.; Koszinowski, U.H.; Jonjic, S.; et al. Ly49P recognition of cytomegalovirus-infected cells expressing H2-Dk and CMV-encoded m04 correlates with the NK cell antiviral response. J. Exp. Med. 2009, 206, 515-523. [CrossRef] 
102. Crespo, A.C.; Strominger, J.L.; Tilburgs, T. Expression of KIR2DS1 by decidual natural killer cells increases their ability to control placental HCMV infection. Proc. Natl. Acad. Sci. USA 2016, 113, 15072-15077. [CrossRef] [PubMed]

103. Kenneson, A.; Cannon, M.J. Review and meta-analysis of the epidemiology of congenital cytomegalovirus (CMV) infection. Rev. Med. Virol. 2007, 17, 253-276. [CrossRef]

104. Schust, D.J.; Tortorella, D.; Seebach, J.; Phan, C.; Ploegh, H.L. Trophoblast class I major histocompatibility complex (MHC) products are resistant to rapid degradation imposed by the human cytomegalovirus (HCMV) gene products US2 and US11. J. Exp. Med. 1998, 188, 497-503. [CrossRef]

105. Gazit, R.; Garty, B.Z.; Monselise, Y.; Hoffer, V.; Finkelstein, Y.; Markel, G.; Katz, G.; Hanna, J.; Achdout, H.; Gruda, R.; et al. Expression of KIR2DL1 on the entire NK cell population: A possible novel immunodeficiency syndrome. Blood 2004, 103, 1965-1966. [CrossRef]

106. Van Duin, D.; Avery, R.K.; Hemachandra, S.; Yen-Lieberman, B.; Zhang, A.; Jain, A.; Butler, R.S.; Barnard, J.; Schold, J.D.; Fung, J.; et al. KIR and HLA interactions are associated with control of primary CMV infection in solid organ transplant recipients. Am. J. Transplant. 2014, 14, 156-162. [CrossRef]

107. Hou, Y.F.; Zhang, Y.C.; Jiao, Y.L.; Wang, L.C.; Li, J.F.; Pan, Z.L.; Yang, Q.R.; Sun, H.S.; Zhao, Y.R. Disparate distribution of activating and inhibitory killer cell immunoglobulin-like receptor genes in patients with systemic lupus erythematosus. Lupus 2010, 19, 20-26. [CrossRef] [PubMed]

108. Pellett, F.; Siannis, F.; Vukin, I.; Lee, P.; Urowitz, M.; Gladman, D. KIRs and autoimmune disease: Studies in systemic lupus erythematosus and scleroderma. In Tissue Antigens; Wiley Online Library: Hoboken, NJ, USA, 2007.

109. Majorczyk, E.; Pawlik, A.; Luszczek, W.; Nowak, I.; Wisniewski, A.; Jasek, M.; Kusnierczyk, P. Associations of killer cell immunoglobulin-like receptor genes with complications of rheumatoid arthritis. Genes Immun. 2007, 8, 678-683. [CrossRef] [PubMed]

110. Hoteit, R.; Bazarbachi, A.; Antar, A.; Salem, Z.; Shammaa, D.; Mahfouz, R. KIR genotype distribution among patients with multiple myeloma: Higher prevalence of KIR 2DS4 and KIR 2DS5 genes. Meta Gene 2014, 2, 730-736. [CrossRef] [PubMed]

111. Coscoy, L.; Ganem, D. Kaposi's sarcoma-associated herpesvirus encodes two proteins that block cell surface display of MHC class I chains by enhancing their endocytosis. Proc. Natl. Acad. Sci. USA 2000, 97, 8051-8056. [CrossRef] [PubMed]

112. Ishido, S.; Wang, C.; Lee, B.S.; Cohen, G.B.; Jung, J.U. Downregulation of major histocompatibility complex class I molecules by Kaposi's sarcoma-associated herpesvirus K3 and K5 proteins. J. Virol. 2000, 74, 5300-5309. [CrossRef] [PubMed]

113. Wang, X.; Lybarger, L.; Connors, R.; Harris, M.R.; Hansen, T.H. Model for the interaction of gammaherpesvirus 68 RING-CH finger protein $\mathrm{mK} 3$ with major histocompatibility complex class I and the peptide-loading complex. J. Virol. 2004, 78, 8673-8686. [CrossRef]

114. Caselli, E.; Rizzo, R.; Ingianni, A.; Contini, P.; Pompei, R.; Di Luca, D. High prevalence of HHV8 infection and specific killer cell immunoglobulin-like receptors allotypes in Sardinian patients with type 2 diabetes mellitus. J. Med. Virol. 2014, 86, 1745-1751. [CrossRef]

115. Borghi, A.; D'Accolti, M.; Rizzo, R.; Virgili, A.; Di Luca, D.; Corazza, M.; Caselli, E. High prevalence of specific KIR types in patients with HHV-8 positive cutaneous vascular lesions: A possible predisposing factor? Arch. Dermatol. Res. 2016, 308, 373-377. [CrossRef]

116. Guerini, F.R.; Mancuso, R.; Agostini, S.; Agliardi, C.; Zanzottera, M.; Hernis, A.; Tourlaki, A.; Calvo, M.G.; Bellinvia, M.; Brambilla, L.; et al. Activating KIR/HLA complexes in classic Kaposi's Sarcoma. Infect. Agent. Cancer 2012, 7, 9. [CrossRef]

117. Eimer, W.A.; Vijaya Kumar, D.K.; Navalpur Shanmugam, N.K.; Rodriguez, A.S.; Mitchell, T.; Washicosky, K.J.; Gyorgy, B.; Breakefield, X.O.; Tanzi, R.E.; Moir, R.D. Alzheimer's disease-associated beta-amyloid is rapidly seeded by herpesviridae to protect against brain infection. Neuron 2018, 99, 56-63. [CrossRef]

118. Rizzo, R.; Bortolotti, D.; Gentili, V.; Rotola, A.; Bolzani, S.; Caselli, E.; Tola, M.R.; Di Luca, D. KIR2DS2/KIR2DL2/HLA-C1 Haplotype is associated with Alzheimer's disease: Implication for the role of herpesvirus infections. J. Alzheimers Dis. 2019, 67, 1379-1389. [CrossRef] [PubMed]

119. Machado-Sulbaran, A.C.; Ramirez-Duenas, M.G.; Navarro-Zarza, J.E.; Munoz-Valle, J.F.; Mendoza-Carrera, F.; Banos-Hernandez, C.J.; Parra-Rojas, I.; Montoya-Buelna, M.; Sanchez-Hernandez, P.E. KIR/HLA gene profile implication in systemic sclerosis patients from Mexico. J. Immunol. Res. 2019, 2019, 6808061. [CrossRef] [PubMed]

120. Ben Fredj, N.; Rizzo, R.; Bortolotti, D.; Nefzi, F.; Chebel, S.; Rotola, A.; Frih-Ayed, M.; Di Luca, D.; Aouni, M. Evaluation of the implication of KIR2DL2 receptor in multiple sclerosis and herpesvirus susceptibility. J. Neuroimmunol. 2014, $271,30-35$. [CrossRef] [PubMed]

121. Bortolotti, D.; Gentili, V.; Santi, E.; Taliento, C.; Vitagliano, A.; Schiuma, G.; Beltrami, S.; Rizzo, S.; Lanza, G.; Rizzo, R.; et al. Late-onset intrauterine growth restriction and HHV-6 infection: A pilot study. J. Med. Virol. 2021. [CrossRef] [PubMed]

122. Rizzo, R.; D'Accolti, M.; Bortolotti, D.; Caccuri, F.; Caruso, A.; Di Luca, D.; Caselli, E. Human herpesvirus 6A and 6B inhibit in vitro angiogenesis by induction of human leukocyte antigen G. Sci. Rep. 2018, 8, 17683. [CrossRef] [PubMed]

123. Komaroff, A.L.; Rizzo, R.; Ecker, J.L. Human herpesviruses 6A and 6B in reproductive diseases. Front. Immunol. 2021, 12, 648945. [CrossRef]

124. Caselli, E.; Bortolotti, D.; Marci, R.; Rotola, A.; Gentili, V.; Soffritti, I.; D’Accolti, M.; Lo Monte, G.; Sicolo, M.; Barao, I.; et al. HHV-6A infection of endometrial epithelial cells induces increased endometrial NK cell-mediated cytotoxicity. Front. Microbiol. 2017, 8, 2525. [CrossRef] 
125. Marci, R.; Gentili, V.; Bortolotti, D.; Lo Monte, G.; Caselli, E.; Bolzani, S.; Rotola, A.; Di Luca, D.; Rizzo, R. Presence of HHV-6A in endometrial epithelial cells from women with primary unexplained infertility. PLoS ONE 2016, 11, e0158304. [CrossRef] [PubMed]

126. Pegoraro, A.; Bortolotti, D.; Marci, R.; Caselli, E.; Falzoni, S.; De Marchi, E.; Di Virgilio, F.; Rizzo, R.; Adinolfi, E. The P2X7 receptor $489 \mathrm{C}>\mathrm{T}$ gain of function polymorphism favors HHV-6A infection and associates with female idiopathic infertility. Front. Pharmacol. 2020, 11, 96. [CrossRef] [PubMed]

127. Rizzo, R.; Lo Monte, G.; Bortolotti, D.; Graziano, A.; Gentili, V.; Di Luca, D.; Marci, R. Impact of soluble HLA-G levels and endometrial NK cells in uterine flushing samples from primary and secondary unexplained infertile women. Int. J. Mol. Sci. 2015, 16, 5510-5516. [CrossRef]

128. Djulejic, E.; Petlickovski, A.; Trajkov, D.; Dimitrov, G.; Alabakovska, S. KIR Gene Frequencies in Women with Infertility Problems. South East Eur. J. Immunol. 2015, 2015, 1-5. [CrossRef]

129. El Borai, N.; Inoue, M.; Lefevre, C.; Naumova, E.N.; Sato, B.; Yamamura, M. Detection of herpes simplex DNA in semen and menstrual blood of individuals attending an infertility clinic. J. Obstet. Gynaecol. Res. 1997, 23, 17-24. [CrossRef]

130. Gimenes, F.; Souza, R.P.; Bento, J.C.; Teixeira, J.J.; Maria-Engler, S.S.; Bonini, M.G.; Consolaro, M.E. Male infertility: A public health issue caused by sexually transmitted pathogens. Nat. Rev. Urol. 2014, 11, 672-687. [CrossRef]

131. Apps, R.; Qi, Y.; Carlson, J.M.; Chen, H.; Gao, X.; Thomas, R.; Yuki, Y.; Del Prete, G.Q.; Goulder, P.; Brumme, Z.L.; et al. Influence of HLA-C expression level on HIV control. Science 2013, 340, 87-91. [CrossRef] [PubMed]

132. Le Gall, S.; Erdtmann, L.; Benichou, S.; Berlioz-Torrent, C.; Liu, L.; Benarous, R.; Heard, J.M.; Schwartz, O. Nef interacts with the mu subunit of clathrin adaptor complexes and reveals a cryptic sorting signal in MHC I molecules. Immunity 1998, 8, $483-495$. [CrossRef]

133. Cohen, G.B.; Gandhi, R.T.; Davis, D.M.; Mandelboim, O.; Chen, B.K.; Strominger, J.L.; Baltimore, D. The selective downregulation of class I major histocompatibility complex proteins by HIV-1 protects HIV-infected cells from NK cells. Immunity 1999, 10, 661-671. [CrossRef]

134. Fadda, L.; Korner, C.; Kumar, S.; van Teijlingen, N.H.; Piechocka-Trocha, A.; Carrington, M.; Altfeld, M. HLA-Cw0102-restricted HIV-1 p24 epitope variants can modulate the binding of the inhibitory KIR2DL2 receptor and primary NK cell function. PLoS Pathog. 2012, 8, e1002805. [CrossRef] [PubMed]

135. Parolini, F.; Biswas, P.; Serena, M.; Sironi, F.; Muraro, V.; Guizzardi, E.; Cazzoletti, L.; Scupoli, M.T.; Gibellini, D.; Ugolotti, E.; et al. Stability and expression levels of HLA-C on the cell membrane modulate HIV-1 infectivity. J. Virol. 2018, 92, e01711-e01717. [CrossRef] [PubMed]

136. Serena, M.; Parolini, F.; Biswas, P.; Sironi, F.; Blanco Miranda, A.; Zoratti, E.; Scupoli, M.T.; Ziglio, S.; Valenzuela-Fernandez, A.; Gibellini, D.; et al. HIV-1 Env associates with HLA-C free-chains at the cell membrane modulating viral infectivity. Sci. Rep. 2017, 7, 40037. [CrossRef]

137. Long, B.R.; Ndhlovu, L.C.; Oksenberg, J.R.; Lanier, L.L.; Hecht, F.M.; Nixon, D.F.; Barbour, J.D. Conferral of enhanced natural killer cell function by KIR3DS1 in early human immunodeficiency virus type 1 infection. J. Virol. 2008, 82, 4785-4792. [CrossRef]

138. Omosun, Y.O.; Blackstock, A.J.; Williamson, J.; van Eijk, A.M.; Ayisi, J.; Otieno, J.; Lal, R.B.; Ter Kuile, F.O.; Slutsker, L.; Shi, Y.P. Association of maternal KIR gene content polymorphisms with reduction in perinatal transmission of HIV-1. PLoS ONE 2018, 13, e0191733. [CrossRef]

139. Sorgho, P.A.; Djigma, F.W.; Martinson, J.J.; Yonli, A.T.; Nagalo, B.M.; Compaore, T.R.; Diarra, B.; Sombie, H.K.; Simpore, A.; Zongo, A.W.; et al. Role of killer cell immunoglobulin-like receptors (KIR) genes in stages of HIV-1 infection among patients from Burkina Faso. Biomol. Concepts 2019, 10, 226-236. [CrossRef]

140. Paximadis, M.; Minevich, G.; Winchester, R.; Schramm, D.B.; Gray, G.E.; Sherman, G.G.; Coovadia, A.H.; Kuhn, L.; Tiemessen, C.T. KIR-HLA and maternal-infant HIV-1 transmission in sub-Saharan Africa. PLoS ONE 2011, 6, e16541. [CrossRef]

141. Martin, M.P.; Gao, X.; Lee, J.-H.; Nelson, G.W.; Detels, R.; Goedert, J.J.; Buchbinder, S.; Hoots, K.; Vlahov, D.; Trowsdale, J. Epistatic interaction between KIR3DS1 and HLA-B delays the progression to AIDS. Nat. Genet. 2002, 31, 429-434. [CrossRef]

142. Khakoo, S.I.; Carrington, M. KIR and disease: A model system or system of models? Immunol. Rev. 2006, 214, 186-201. [CrossRef] [PubMed]

143. Ravet, S.; Scott-Algara, D.; Bonnet, E.; Tran, H.K.; Tran, T.; Nguyen, N.; Truong, L.X.; Theodorou, I.; Barre-Sinoussi, F.; Pancino, G.; et al. Distinctive NK-cell receptor repertoires sustain high-level constitutive NK-cell activation in HIV-exposed uninfected individuals. Blood 2007, 109, 4296-4305. [CrossRef] [PubMed]

144. Boulet, S.; Sharafi, S.; Simic, N.; Bruneau, J.; Routy, J.P.; Tsoukas, C.M.; Bernard, N.F. Increased proportion of KIR3DS1 homozygotes in HIV-exposed uninfected individuals. AIDS 2008, 22, 595-599. [CrossRef]

145. Shah-Hosseini, A.; Jafari, M.; Mohammadi, A.; Sanaei, R.; Alavian, S.M.; Doosti-Irani, A.; Nooradeh Keykavousi, M.; Tajik, N. The impact of KIR-HLA genotype on hepatitis B virus clearance in Iranian infected individuals. Med. Microbiol. Immunol. 2017, 206, 463-470. [CrossRef] [PubMed]

146. Jamil, K.M.; Khakoo, S.I. KIR/HLA interactions and pathogen immunity. J. Biomed. Biotechnol. 2011, 2011, 298348. [CrossRef] [PubMed]

147. Di Bona, D.; Aiello, A.; Colomba, C.; Bilancia, M.; Accardi, G.; Rubino, R.; Giannitrapani, L.; Tuttolomondo, A.; Cascio, A.; Caiaffa, M.F.; et al. KIR2DL3 and the KIR ligand groups HLA-A-Bw4 and HLA-C2 predict the outcome of hepatitis B virus infection. J. Viral Hepat. 2017, 24, 768-775. [CrossRef] 
148. Lu, Z.; Zhang, B.; Chen, S.; Gai, Z.; Feng, Z.; Liu, X.; Liu, Y.; Wen, X.; Li, L.; Jiao, Y.; et al. Association of KIR genotypes and haplotypes with susceptibility to chronic hepatitis B virus infection in Chinese Han population. Cell. Mol. Immunol. 2008, 5, 457-463. [CrossRef]

149. Kibar, F.; Goruroglu Ozturk, O.; Ulu, A.; Erken, E.; Inal, S.; Dinkci, S.; Kurtaran, B.; Tasova, Y.; Aksu, H.S.; Yaman, A. Role of KIR genes and genotypes in susceptibility to or protection against hepatitis B virus infection in a Turkish cohort. Med. Sci. Monit. 2014, 20, 28-34. [CrossRef] [PubMed]

150. Pan, N.; Jiang, W.; Sun, H.; Miao, F.; Qiu, J.; Jin, H.; Xu, J.; Shi, Q.; Xie, W.; Zhang, J. KIR and HLA loci are associated with hepatocellular carcinoma development in patients with hepatitis B virus infection: A case-control study. PLoS ONE 2011, 6, e25682. [CrossRef] [PubMed]

151. Suppiah, V.; Gaudieri, S.; Armstrong, N.J.; O'Connor, K.S.; Berg, T.; Weltman, M.; Abate, M.L.; Spengler, U.; Bassendine, M.; Dore, G.J.; et al. IL28B, HLA-C, and KIR variants additively predict response to therapy in chronic hepatitis C virus infection in a European Cohort: A cross-sectional study. PLoS Med. 2011, 8, e1001092. [CrossRef] [PubMed]

152. Golden-Mason, L.; Bambha, K.M.; Cheng, L.; Howell, C.D.; Taylor, M.W.; Clark, P.J.; Afdhal, N.; Rosen, H.R.; Virahep, C.S.G. Natural killer inhibitory receptor expression associated with treatment failure and interleukin-28B genotype in patients with chronic hepatitis C. Hepatology 2011, 54, 1559-1569. [CrossRef]

153. Lunemann, S.; Martrus, G.; Holzemer, A.; Chapel, A.; Ziegler, M.; Korner, C.; Garcia Beltran, W.; Carrington, M.; Wedemeyer, H.; Altfeld, M. Sequence variations in HCV core-derived epitopes alter binding of KIR2DL3 to HLA-C *03:04 and modulate NK cell function. J. Hepatol. 2016, 65, 252-258. [CrossRef]

154. Schneidewind, A.; Brockman, M.A.; Yang, R.; Adam, R.I.; Li, B.; Le Gall, S.; Rinaldo, C.R.; Craggs, S.L.; Allgaier, R.L.; Power, K.A.; et al. Escape from the dominant HLA-B27-restricted cytotoxic T-lymphocyte response in Gag is associated with a dramatic reduction in human immunodeficiency virus type 1 replication. J. Virol. 2007, 81, 12382-12393. [CrossRef]

155. Marcilla, M.; Lopez de Castro, J.A. Peptides: The cornerstone of HLA-B27 biology and pathogenetic role in spondyloarthritis. Tissue Antigens 2008, 71, 495-506. [CrossRef]

156. Stewart-Jones, G.B.; di Gleria, K.; Kollnberger, S.; McMichael, A.J.; Jones, E.Y.; Bowness, P. Crystal structures and KIR3DL1 recognition of three immunodominant viral peptides complexed to HLA-B*2705. Eur. J. Immunol. 2005, 35, 341-351. [CrossRef]

157. Oliviero, B.; Varchetta, S.; Paudice, E.; Michelone, G.; Zaramella, M.; Mavilio, D.; De Filippi, F.; Bruno, S.; Mondelli, M.U. Natural killer cell functional dichotomy in chronic hepatitis B and chronic hepatitis C virus infections. Gastroenterology 2009, 137, 1151-1160. [CrossRef]

158. Njiomegnie, G.F.; Read, S.A.; Fewings, N.; George, J.; McKay, F.; Ahlenstiel, G. Immunomodulation of the natural killer cell phenotype and response during HCV infection. J. Clin. Med. 2020, 9, 1030. [CrossRef] [PubMed]

159. De Re, V.; Caggiari, L.; De Zorzi, M.; Repetto, O.; Zignego, A.L.; Izzo, F.; Tornesello, M.L.; Buonaguro, F.M.; Mangia, A.; Sansonno, D.; et al. Genetic diversity of the KIR/HLA system and susceptibility to hepatitis C virus-related diseases. PLoS ONE 2015, 10, e0117420. [CrossRef]

160. Knapp, S.; Warshow, U.; Hegazy, D.; Brackenbury, L.; Guha, I.N.; Fowell, A.; Little, A.M.; Alexander, G.J.; Rosenberg, W.M.; Cramp, M.E.; et al. Consistent beneficial effects of killer cell immunoglobulin-like receptor 2DL3 and group 1 human leukocyte antigen-C following exposure to hepatitis $C$ virus. Hepatology 2010, 51, 1168-1175. [CrossRef] [PubMed]

161. Ahlenstiel, G.; Martin, M.P.; Gao, X.; Carrington, M.; Rehermann, B. Distinct KIR/HLA compound genotypes affect the kinetics of human antiviral natural killer cell responses. J. Clin. Investig. 2008, 118, 1017-1026. [CrossRef]

162. Qin, H.; Wang, Z.; Du, W.; Lee, W.H.; Wu, X.; Riggs, A.D.; Liu, C.P. Killer cell Ig-like receptor (KIR) 3DL1 down-regulation enhances inhibition of type 1 diabetes by autoantigen-specific regulatory T cells. Proc. Natl. Acad. Sci. USA 2011, 108, $2016-2021$. [CrossRef] [PubMed]

163. Weider, T.; Richardson, S.J.; Morgan, N.G.; Paulsen, T.H.; Dahl-Jorgensen, K.; Hammerstad, S.S. Upregulation of HLA class I and antiviral tissue responses in Hashimoto's thyroiditis. Thyroid 2020, 30, 432-442. [CrossRef]

164. Aslanidis, S.; Pyrpasopoulou, A.; Kontotasios, K.; Doumas, S.; Zamboulis, C. Parvovirus B19 infection and systemic lupus erythematosus: Activation of an aberrant pathway? Eur. J. Intern. Med. 2008, 19, 314-318. [CrossRef] [PubMed]

165. Gasser, S.; Raulet, D. The DNA damage response, immunity and cancer. In Seminars in Cancer Biology; Academic Press: Cambridge, MA, USA, 2006; pp. 344-347.

166. Rizzo, R.; Gentili, V.; Rotola, A.; Bortolotti, D.; Cassai, E.; Di Luca, D. Implication of HLA-C and KIR alleles in human papillomavirus infection and associated cervical lesions. Viral Immunol. 2014, 27, 468-470. [CrossRef]

167. Kollnberger, S.; Bird, L.; Sun, M.Y.; Retiere, C.; Braud, V.M.; McMichael, A.; Bowness, P. Cell-surface expression and immune receptor recognition of HLA-B27 homodimers. Arthritis Rheum. 2002, 46, 2972-2982. [CrossRef]

168. Garcia-Beltran, W.F.; Holzemer, A.; Martrus, G.; Chung, A.W.; Pacheco, Y.; Simoneau, C.R.; Rucevic, M.; Lamothe-Molina, P.A.; Pertel, T.; Kim, T.E.; et al. Open conformers of HLA-F are high-affinity ligands of the activating NK-cell receptor KIR3DS1. Nat. Immunol. 2016, 17, 1067-1074. [CrossRef]

169. Burian, A.; Wang, K.L.; Finton, K.A.; Lee, N.; Ishitani, A.; Strong, R.K.; Geraghty, D.E. HLA-F and MHC-I open conformers bind natural killer cell Ig-like receptor KIR3DS1. PLoS ONE 2016, 11, e0163297. [CrossRef]

170. Cook, M.; Briggs, D.; Craddock, C.; Mahendra, P.; Milligan, D.; Fegan, C.; Darbyshire, P.; Lawson, S.; Boxall, E.; Moss, P. Donor KIR genotype has a major influence on the rate of cytomegalovirus reactivation following T-cell replete stem cell transplantation. Blood 2006, 107, 1230-1232. [CrossRef] [PubMed] 
171. Agrawal, S.; Prakash, S. Significance of KIR like natural killer cell receptors in autoimmune disorders. Clin. Immunol. 2020, $216,108449$. [CrossRef] [PubMed]

172. Hou, Y.; Zhang, C.; Xu, D.; Sun, H. Association of killer cell immunoglobulin-like receptor and human leucocyte antigen-C w gene combinations with systemic lupus erythematosus. Clin. Exp. Immunol. 2015, 180, 250-254. [CrossRef]

173. Beck, S.; Barrell, B.G. Human cytomegalovirus encodes a glycoprotein homologous to MHC class-I antigens. Nature 1988, 331, 269-272. [CrossRef] [PubMed]

174. Rizzo, R. Controversial role of herpesviruses in Alzheimer's disease. PLoS Pathog. 2020, 16, e1008575. [CrossRef]

175. Itzhaki, R.F. Herpes simplex virus type 1 and Alzheimer's disease: Increasing evidence for a major role of the virus. Front. Aging Neurosci. 2014, 6, 202. [CrossRef]

176. Readhead, B.; Haure-Mirande, J.V.; Funk, C.C.; Richards, M.A.; Shannon, P.; Haroutunian, V.; Sano, M.; Liang, W.S.; Beckmann, N.D.; Price, N.D.; et al. Multiscale analysis of independent Alzheimer's cohorts finds disruption of molecular, genetic, and clinical networks by human herpesvirus. Neuron 2018, 99, 64-82.e67. [CrossRef]

177. Challoner, P.B.; Smith, K.T.; Parker, J.D.; MacLeod, D.L.; Coulter, S.N.; Rose, T.M.; Schultz, E.R.; Bennett, J.L.; Garber, R.L.; Chang, M.; et al. Plaque-associated expression of human herpesvirus 6 in multiple sclerosis. Proc. Natl. Acad. Sci. USA 1995, 92, 7440-7444. [CrossRef]

178. Alvarez-Lafuente, R.; De las Heras, V.; Bartolome, M.; Picazo, J.J.; Arroyo, R. Relapsing-remitting multiple sclerosis and human herpesvirus 6 active infection. Arch. Neurol. 2004, 61, 1523-1527. [CrossRef]

179. Gómez-Lozano, N.; de Pablo, R.; Puente, S.; Vilches, C. Recognition of HLA-G by the NK cell receptor KIR2DL4 is not essential for human reproduction. Eur. J. Immunol. 2003, 33, 639-644. [CrossRef]

180. Boulet, S.; Kleyman, M.; Kim, J.Y.; Kamya, P.; Sharafi, S.; Simic, N.; Bruneau, J.; Routy, J.P.; Tsoukas, C.M.; Bernard, N.F. A combined genotype of KIR3DL1 high expressing alleles and HLA-B*57 is associated with a reduced risk of HIV infection. AIDS 2008, 22, 1487-1491. [CrossRef] [PubMed]

181. Jennes, W.; Verheyden, S.; Demanet, C.; Menten, J.; Vuylsteke, B.; Nkengasong, J.N.; Kestens, L. Low CD4+ T cell counts among African HIV-1 infected subjects with group B KIR haplotypes in the absence of specific inhibitory KIR ligands. PLoS ONE 2011, 6, e17043. [CrossRef] [PubMed]

182. Roeth, J.F.; Williams, M.; Kasper, M.R.; Filzen, T.M.; Collins, K.L. HIV-1 Nef disrupts MHC-I trafficking by recruiting AP-1 to the MHC-I cytoplasmic tail. J. Cell Biol. 2004, 167, 903-913. [CrossRef]

183. Wonderlich, E.R.; Williams, M.; Collins, K.L. The tyrosine binding pocket in the adaptor protein 1 (AP-1) mu1 subunit is necessary for Nef to recruit AP-1 to the major histocompatibility complex class I cytoplasmic tail. J. Biol. Chem. 2008, 283, 3011-3022. [CrossRef]

184. Vidricaire, G.; Imbeault, M.; Tremblay, M.J. Endocytic host cell machinery plays a dominant role in intracellular trafficking of incoming human immunodeficiency virus type 1 in human placental trophoblasts. J. Virol. 2004, 78, 11904-11915. [CrossRef] [PubMed]

185. Martin, M.P.; Qi, Y.; Gao, X.; Yamada, E.; Martin, J.N.; Pereyra, F.; Colombo, S.; Brown, E.E.; Shupert, W.L.; Phair, J.; et al. Innate partnership of HLA-B and KIR3DL1 subtypes against HIV-1. Nat. Genet. 2007, 39, 733-740. [CrossRef]

186. Qi, Y.; Martin, M.P.; Gao, X.; Jacobson, L.; Goedert, J.J.; Buchbinder, S.; Kirk, G.D.; O’Brien, S.J.; Trowsdale, J.; Carrington, M. KIR/HLA pleiotropism: Protection against both HIV and opportunistic infections. PLoS Pathog. 2006, 2, 741-745. [CrossRef]

187. Singh, R.; Kaul, R.; Kaul, A.; Khan, K. A comparative review of HLA associations with hepatitis B and C viral infections across global populations. World J. Gastroenterol. 2007, 13, 1770-1787. [CrossRef] [PubMed]

188. Blackwell, J.M.; Jamieson, S.E.; Burgner, D. HLA and infectious diseases. Clin. Microbiol. Rev. 2009, 22, 370-385. [CrossRef] [PubMed]

189. Chen, Y.; Wei, H.; Gao, B.; Hu, Z.; Zheng, S.; Tian, Z. Activation and function of hepatic NK cells in hepatitis B infection: An underinvestigated innate immune response. J. Viral Hepat. 2005, 12, 38-45. [CrossRef] [PubMed]

190. Burt, B.M.; Plitas, G.; Zhao, Z.; Bamboat, Z.M.; Nguyen, H.M.; Dupont, B.; DeMatteo, R.P. The lytic potential of human liver NK cells is restricted by their limited expression of inhibitory killer Ig-like receptors. J. Immunol. 2009, 183, 1789-1796. [CrossRef]

191. Crispe, I.N. The liver as a lymphoid organ. Annu. Rev. Immunol. 2009, 27, 147-163. [CrossRef]

192. Protzer, U.; Maini, M.K.; Knolle, P.A. Living in the liver: Hepatic infections. Nat. Rev. Immunol. 2012, 12, 201-213. [CrossRef] [PubMed]

193. Tu, Z.; Bozorgzadeh, A.; Pierce, R.H.; Kurtis, J.; Crispe, I.N.; Orloff, M.S. TLR-dependent cross talk between human Kupffer cells and NK cells. J. Exp. Med. 2008, 205, 233-244. [CrossRef] [PubMed]

194. Chen, Y.; Wei, H.; Sun, R.; Dong, Z.; Zhang, J.; Tian, Z. Increased susceptibility to liver injury in hepatitis B virus transgenic mice involves NKG2D-ligand interaction and natural killer cells. Hepatology 2007, 46, 706-715. [CrossRef]

195. Parham, P.; Abi-Rached, L.; Matevosyan, L.; Moesta, A.K.; Norman, P.J.; Older Aguilar, A.M.; Guethlein, L.A. Primate-specific regulation of natural killer cells. J. Med. Primatol. 2010, 39, 194-212. [CrossRef] [PubMed]

196. Ursu, L.D.; Calenic, B.; Diculescu, M.; Dima, A.; Stoian, I.T.; Constantinescu, I. Clinical and histopathological changes in different KIR gene profiles in chronic HCV Romanian patients. Int. J. Immunogenet. 2021, 48, 16-24. [CrossRef] [PubMed]

197. Larkin, J.; Bost, A.; Glass, J.I.; Tan, S.L. Cytokine-activated natural killer cells exert direct killing of hepatoma cells harboring hepatitis C virus replicons. J. Interferon Cytokine Res. 2006, 26, 854-865. [CrossRef] [PubMed] 
198. Stegmann, K.A.; Bjorkstrom, N.K.; Veber, H.; Ciesek, S.; Riese, P.; Wiegand, J.; Hadem, J.; Suneetha, P.V.; Jaroszewicz, J.; Wang, C.; et al. Interferon-alpha-induced TRAIL on natural killer cells is associated with control of hepatitis $C$ virus infection. Gastroenterology 2010, 138, 1885-1897. [CrossRef] [PubMed]

199. Nitschke, K.; Barriga, A.; Schmidt, J.; Timm, J.; Viazov, S.; Kuntzen, T.; Kim, A.Y.; Lauer, G.M.; Allen, T.M.; Gaudieri, S.; et al. HLA-B*27 subtype specificity determines targeting and viral evolution of a hepatitis $C$ virus-specific CD8+ T cell epitope. J. Hepatol. 2014, 60, 22-29. [CrossRef] [PubMed]

200. Hausen, H.z. Papillomavirus infections-a major cause of human cancers. Biochim. Biophys. Acta Rev. Cancer 1996, 1288, F55-F78. [CrossRef] 